\title{
ASPECTOS DA PESCA DA BALEIA NO BRASIL COLONIAL (III).
}

(Notas prévias de um trabalho em preparo).

(Conclusão).

\section{VI. - A PESCA DA BALEIA E AS ARMAÇõES DEPOIS DO ALVARA' DE 24 DE ABRIL DE 1801.}

Antecedentes do Alvatá de 24 de abril de 1801. O Alvará e seus objetivas. A regulamentação estabelecida para a pesca da baleia no Brasil. A administração da pesca. As Armações.

Antes da supressão do monopólio da pesca às baleias em 1801, a Corôa portuguêsa permitiu, em fins do século XVIII, a "pesca volante" do cetáceo em alto mar. E' que "graves inconvenientes" e "grande diminuição" resultavam para a Marinha Mercante, das restrições impostas até então àquêle tipo de pesca e do privilégio dos Contratos que não permitiam em qualquer parte do Reino e suas colônias outras "armações sedentárias" além das que se achassem expressamente autorizadas.

Os Contratos da baleia não possuindo a exclusividade das "Pescarias Volantes" e os Contratadores cedendo parte de seus direitos em benefício da Fazenda Real para a construção de "armações sedentátias" em "qualquer parte das Ilhas de Cabo Verde", a Corôa, em maio de 1798 determinou o seguinte:

1. que todos os negociantes portuguêses, isoladamente ou em sociedade, pudessem armar navios em tôdas as costas de Portugal, do Brasil e de Moçambique, para a pesca da baleia, bem como preparar o azeite em alto mar, podendo vendê-lo, inclusive as barbatanas, - mesmo para fora do Reino - de acôrdo com as condições estipuladas nos Contratos.

2. que em quaisquer das Ilhas do Cabo Verde, seria permitido a todo negociante português estabelecer "Pes" carias sedentárias" e "Armazéns para o mesmo fim". 
3. que todos os pescadores de baleia estrangeiros que servissem em navios lusitanos nas "Pescarias Volantes", depois de dez anos sucessivos, obteriam os mesmos privilégios conceflidos aos portuguêses, naturalizando-se vassalos da Corôa.

4. estas concessões deveriam estender-se a todos os súditos em todos os dominios de Portugal, quer na Metrópole ou no Ultramar (1).

Era o prelúdio da supressão do monopólio da pesca da baleia no Brasil.

O alvará de 24 de abril de 1801, que aboliu o estanque do sal no Brasil e o regime de contratos da baleia, permitiu não só que a pesca do cetáceo se estendesse a todo o litoral da Colônia, como procurou incentivar o seu desenvolvimento para o alto mar,

" (...) conforme o praticão as Nações mais industriosas da Europa (...), para haver (...) maior abundancia de Azeite de Peixe, e por consequencia huma diminuição sensivel no preço actual deste genero tão preciso para o Serviço da Marinha, Fabricas e Uso particular (...)" (2).

Terminava o "Privilégio Exclusivo" da Real Fazenda no Brasil.

Os Governadores das Capitanias, de comum acôrdo com as respectivas Juntas da Fazenda, deveriam promover inventários dos escravos, armações e utensílios pertencentes à pescaria das baleias providenciando a sua venda, à vista ou a prazo, em conjunto ou em partes. Não aparecendo compradores, deveriam colocar as pescarias em administração ou procurar estabelecer sociedades de negociantes que se encarregassem da escravatura e do material das armações, continuando e desenvolvendo as pescarias, sem qualquer privilégio ou exclusividade comercial, ficando obrigados ùnicamente ao pagamento de direitos,

(1). - Departamento do Arquivo do Estado de São Paulo - Leis de Portugal vol. de 1732 a 1799. "Alvará por que Vossa Magestade ha por bem permittir que todos os Negociantes possão preparar, e armar Navios, destinados a pescar as Balêas, e preparar o seu Azeite no Alto Mar, ficando-lhes livre poder fazer Pescarias sedentarias nas Ilhas de Cabo Verde; tudo na forma assima declarada. Dado no Palacio de Queluz em 18 de Maio de 1798". Impresso na Régia Oficina Tipográfica.

O Alvará foi promulgado em nome da Rainha e assinado pelo príncipe D. João, na qualidade de Regente.

Governadores e Capitães Generais do Brasil deveriam animar e proteger os negociantes que quizessem empreender as "Pescarias Volantes".

Departamento do Arquivo do Estado de São Paulo - Livro n.o 73, Tempo Colonial, "Avisos e Cartas Régias - 1796-1802". "Ofício de D. Rodrigo de Souza Coutinho, datado do Palacio de Queluz, a 12 de junho de 1798, ao Capitão-General da Capitania de São Paulo, Antônio Manuel de Melo Castro e Mendonça, remetendo um Alvará incluso, pelo qual Sua Mage. permitte a "Pesca Volante" das Baleas no Alto Mar, e que se possão estabelecer Pescarias sedentarias nas Ilhas de Cabo Verde. Diz ainda, que a Rainha manda recomendar que o Capitão General procure animar e proteger todos os nego. ciantes que quizprem empreender as referidas Pescarias volanteș... Cópia, 2a. via. (Manuscrito Inédito).

(2). - "Alvará do Príncipe Regente, D. João, de 24 de abril de 1801, abolindo o contrato do Estanque do Sal e o da pescaria das baleias", loc. cit. 


\author{
"competentes" e a "satisfazer" à Real Fazenda “( . . ) \\ o que da mesma receberem (...)".
}

No caso de maior conveniência no estabelecimento de uma sociedade interessada na pesca da baleia, a Fazenda Real poderia tomar parte, com um capital correspondente ao valor das "Fábricas" (3).

Ao terminar em 1801 o último contrato da pesca da baleia e, antes do recebimento do Alvará de 24 de abril, a Junta da Fazenda Real do Rio de Janeiro administrou temporàriamente por meio de um Assento a pesca, de São Sebastião até ao Sul. E' o que diz o

"Ofício do Conselheiro Chanceler Deputado da mesma Junta, Luis Beltrão de Gouveia de Almeida ao Visconde de Anadia, datado do Rio de Janeiro, a 29 de dezembro de 1801, sôbre o estado da pesca da baleia que a Junta promoveu por administração e quais foram os resultados" (4).

O resultado da pesca da baleia feita por Administração determinada pela Junta da Fazenda Real, do Rio de Janeiro, no Assento estabelecido a 11 de abril de 1801, foi o seguinte, de acôrdo $\operatorname{com} a$

"Lista das Baleas que se pescarâo por conta da Real Fa-
zenda na repartição do Rio de Janeiro no prezente anno
de 1801. Armaçoens Baleas Gibartes

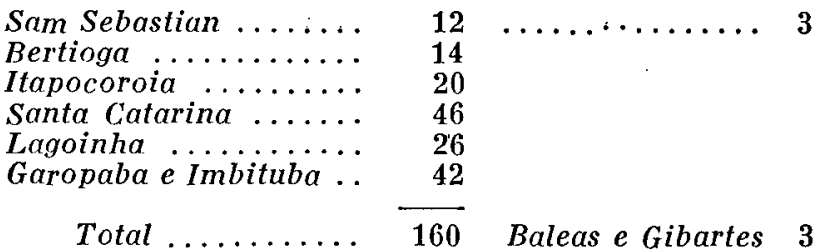

160 Baleas produzem 2.400 pipas de azeite, que dão pelo preçó de 320 a medida a quantia de $153.600 \$ 000$ rs. de que extraida a Despeza, pela importancia de huma conta aproximada á dos annos anteriores, deve restar o lucro de $100: 000 \$ 0000$ rs." (5).

(3). - "Alvará de 24 de abril de 1801, etc.", loc. cit. Para que a Fazenda Real fôsse indenizada de perdas dos rendimentos resultantes dos monopólios do sal e da pesca da baleia, seriam estabelecidos alguns novos impostos; seria criada uma Administração Régia para o sal exportado do Reino e seriam considerados gêneros privativos da Real Fazenda, o salitre e a pólvora.

(4). - Arquivo Histórico Ultramarina de Lisboa. Documentos Avulsos do Rio de Janeiro, caixa de 1802, "Ofício, etc.", com mais documentos anexos. Anexo 1.0. Cópia. (Manuscrito Inédito).

(5). - Arquivo Histórico Ultramarino de Lisboa. Documentos Avulsos do Rio de Janeiro, caixa de 1802 . "Oficio do Conselheiro Chanceler Deputado da Junta 
Daquele Assento, a Fazenda Real do Rio de Janeiro auferiu mais de 200.000 cruzados, resultantes da pesca e do azeite recebido do

$$
\text { “(...) concluido contrato". }
$$

Contra o Assento que funcionou provisòriamente entre o regime de Contratos e o de liberdade de pesca, houve um despacho do Conde de Rezende de 28 de março de 1801, mandando continuar o privilégio dos últimos Contratadores

$$
\text { “( } . .) \text { por hum anno de providencia }(. . .) \text { " }
$$

até haver nova arrematação. Não teve efeito o despacho por influência e atuação do Conselheiro Chanceler Deputado da Junta da Fazenda Luís Beltrão de Gouveia de Almeida.

O Alvará de 24 de abril chegou ao Rio de Janeiro em agôsto sòmente a daí por diante é que começou a vigorar a liberdade da pesca da baleia no Brasil. Até fins de dezembro de 1801 não houve qualquer oferta para aquisição do espólio dos contratos (6), "fábricas", capelas, casas, escravos e utensílios, apesar dos editais enviados a tôdas as pessoas da Capitania que poderiam interessarse pelo negócio. E' que seria dispendiosa a aquisição, principalmente naquela época, em que os gêneros do país haviam sofrido uma baixa de preços e os comerciantes do Rio de Janeiro tinham capitais empatados em outras negociações. Apareceram, entretanto, propostas em 1802, feitas por comerciantes da Praça do Rio de Janeiro, para o estabelecimento de sociedades em que fôsse interessada a Fazenda Real no sentido da exploração da pesca da baleia. De acôrdo com uma das propostas entraria a Fazenda Real com um capital correspondente aos escravos, estabelecimentos e apetrechos para a prática da pesca. Tudo num valor de quase 900.000 cruzados. Os comerciantes entrariam com o trabalho, o custeio da pesca, a manutenção das armações e a fabricação do azeite (7). Seria muito

da Fazenda, Luís Beltrão de Gouveia de Almeida, a D. Rodrigo de Souza Coutinho, de 26 de dezembro de 1801, sôbre o estado da pesca da baleia, etc.", remetendo a "Lista das Baleas que se pescarão por conta da Real Fazendá na repartição do Rio de Janeiro, no prezente anno de 1801". Cópia. (Manuscrito Inédito), loc, cit.

Quanto à expressão "Gibarte" ou "Jubarte", diz Victor Meunier, à pág. 81 de "Les grandes pêches" que era a "baleine à aileron dorsal". E' a "Megaptera", Mário Ruspoli, "A la recherche du Cachalot", pág. 90.

(6). - Arquivo Histórico Ultramarino de Lisboa. Documentos Avulsos do Rio de Janeiro, caixa de 1802. "Ofício do Conselheiro Chanceler da Relaçāo do Rio de Janeiro, Luís Beltrão de Gouvea de Almeida, etc.", loc. cit.

(7). - Arquivo Histórico Ultramarino de Lisboa Documentos Ávulsos do Rio de Janeiro, caixa de 1802. "Ofício de D. Fernando José de Portugal ao Visconde de Anadia, datado do Rio de Janeiro, a 20 de maio de 1802 , em observância do Alvará de 24 de abril de 1801, enviando plenos dos comerciantes do Rio de Janeiro concernentes ao estabelecimento de uma sociedade para a pesca da baleia no Brasil". Cópia. (Manuscrito Inédito). Com documentos anexos. Loc. cit. 
mais vantajoso para a Fazenda Real do que administrar por conta própria a pesca da baleia. Os sistemas de Administração eram sempre menos úteis à Fazenda Real do que os Contratos e Arrematações que garantiam sempre os interêsses régios (8).

Outra proposta, tendo por base o estabelecimento de uma sociedade ou Companhia por ações, partiu do Deputado Secretário da mesa da Inspeç̧ão, Manuel Moreira de Figueiredo e foi assinado por 40 comerciantes $(9)$.

De acôrdo com o primeiro plano, os lucros e as perdas seriam divididos em três partes, cabendo duas partes à Fazenda Real. Quanto ao segundo, a Companhia formada fundaria um Banco de empréstimo e de desconto a favor do comércio e em benefício da Agricultura, por tempo indeterminado. A Junta da Real Fazenda do Rio de Janeiro foi favorável ao primeiro projeto (10).

Parece, entretanto, que a Corôa portuguêsa nada deliberou naquele sentido. No Rio de Janeiro não houve quem quisesse comprar as armações da região, tão pouco as instaladas no litoral sul; na Bahia, porém, diz Monsenhor Pizarro nas suas "Memórias Históricas do Rio de Janeiro" que as duas ali existentes, a de Itaparica e a de Itapoã foram vendidas (11). Diz ainda, que foram construídas outras, de lucros insignificantes, no entanto,

“( . . ) por constar a pesca de gibartes (uma das vinte e tantas espécies de baleias) que apenas rendem de 8 a 12 pipas de azeite, ficando inútil a barbatana, e muito por acaso pescar-se naqueles mares alguma baleia do mar do sul, mais rendosa em azeite, e de barbatana servivel" (12).

Entre 1817 e 1820 , Spix e Martius registraram referências às fábricas e armações da Bahia que se encontravam na barra entre - mar e a Capela de São Bento, sendo que ao norte da barra, se erguiam as armações de Itapoã. Registraram, também, as impressões sôbre a Ilha de Itaparica, em cujo pôrto existiam

\footnotetext{
(8). - Arquivo Histórico Ultramarino de Lisboa. Documentos Avulsos do Rio de Janeiro, caixa de 1802 - Documento anexo ao "Ofício de D. Fernando José de Portugal no Visconde de Anadia, datado do Rio de Janeiro a 20 de maio de $1802 \ldots$.., loc. cit. E' o anexo n. 3 . "Resposta e parecer do Desembargador Procurador da Corôa e Fazenda, Francisco de Souza Guerra e Araújo Godinho, de 4 de abril de 1801, sôbre um projeto de comerciantes do Rio de Janeiro relativo ao estabelecimento de uma sociedade com a Fazenda Real para a pesca da baleia". Cópia. (Manuscrito Inédito).

(9). - Idem, anexo n.0 7. "Plano para se realizarem as Paternais Providências com que Sua Alteza Real pelos Alvarás de 18 de maio de 1798 , e de 24 de abril de 1801 , atendendo ao uzo diario, e indespensavel do azeite de peixe, $q^{\prime}$ se hia tornando raro, se dignou a bem dos seos fieis vasalos Ordenar o aumento da pesca das Baleas para a abastança e bom preço do dito genero. Rio de Janeiro, 14 de abril de 1802". Cópia. (Manuscrito Inédito).

(10). - Arquivo Histórico Ultramarino de Lisboa. Documentos Avulsos do Rio de Janeiro, caixa de 1802. "Ofício de D. Fernando José de Portugal ao Visconde de Anacia, datado do Rio de Janeiro a 20 de maio de 1802 ..., etc.", loc. cit.

(11). - Pizarro e Araújo, op. cit. 9.0 vol., pág. 264
}

(12). - Idem, pág. 265. 
“(...) diversas fábricas de azeite de baleia e grande número de crânios e costelas (...)" de que emanava "(...) insuportável mau cheiro (...)" "empestando" o ambiente.

As fábricas, ou refinações eram precárias pelo tamanho e pela ausência de instalações adequiadas e utensílios apropriados. Apesar disso, o azeite era exportado em pipas de 60 a 70 canadas. Uma canada ficava em 700 ou 750 réis (13).

Quanto às demais armações do litoral brasileiro, resolveu a Corôa mantê-las por sua conta até meados de 1816. Nesse período, foi fundada em 1807 mais uma. Construiram-na na Ilha da Graça, na barra norte do rio de São Francisco, no litoral catarinense. Foi suplemento da armação de Itapocoróia.

A administração real manifestou, entretanto, durante todo êsse tempo, pouco interêsse pela pesca da baleia, descuidando-se das armações e de tudo quanto se relacionasse com elas, inclusive do pagamento de baleeiros e mais empregados (14).

Em Santa Catarina, por exemplo, a má administração da Fazenda Real contribuiu para a decadência da pesca, não fornecendo dinheiro para a manutenção das armações (15).

Por falta de salários, o que sucedeu durante três anos seguidos, fugiam os homens que se dedicavam à arriscada atividade. Era necessário mandar prendê-los, tal como aconteceu em 1813 e 1814. Porém, novamente se evaderiam, se os Administradores não os pagassem com recursos do próprio bôlso.

Conseqüentemente as pescas diminuiram ainda mais. Em 1813 foram mortas apenas 34 baleias nas seis armações existentes no litoral catarinense (16).

\footnotetext{
(13). - J. B. von Spix e C. F. P. von Martius, "Viagem pelo Brasil", 2.0 volume, págs. $272,273,284,276$.

Os autcres mencionam nessa época o fechamento das armações de Itapoan.

(14). $\longrightarrow$ Idem, ibidem.

(15). - Esse mal parece ter existido em Santa Catarina desde o tempo do regime de contrato da pesca da baleia. Em 1797 era grande a divida da Fazenda Real para com a Capitania, que era a mais pobre e não possuia rendimentos suficientes para a sua despêsa. A tropa e os empregados públicos esperavam sempre que a Junta da Fazenda do Rio de Janeiro quisesse " (...) por caridade mandar-lhes por esmola parte dos ordenados e soldos que ganhavão com o suor do seu rosto no serviço do Estado". Enquanto isso as outras Capitanias enviavam grande sobras para o Erário Régio de Lisboa. Do contrato da baleia a Capitania de Santa Catarina só recebia 4:000\$000 anualmente". Paulo José Migurel de Brito, "Memoria Politica sobre a Capitania de Santa Catharina. Escripta no Rio de Janeiro em o anno de 1816", págs. 102 e 103 . Menciona, ainda, o autor, à pág. 103, o estado miserável em que no ano de 1816 se encontravarm as armações de Santa Catarina. Enquanto a Fazenda Real administrava mal, os Contratadores, entretanto, mantinham as armações com tudo o que era necessário e pagavam os empregados a tempo e generosamente. Terminando o sistema de Contratos, a pesca da baleia passou à administração da Fą̧enda Real; o fato contribuiu, sem dúvida, para a sua decarlência. Ver pág. 104.

(16). - Paulo José Miguel de Brito, op. cit., págs. 103, 104, nota 10. Diz o Autor que essas 34 baleias produziram 510 pipas de azeite de 200 medidas; o azeite vendido a 200 rs. a medida, o lucro seria de $20: 400 \$ 000$, que não da-
} 
Freqüentemnte a administração real aproveitava os soldados do Regimento da terra nas armações (17). Eram homens que tinham 16 ou mais anos de serviço ativo, pobres e maltrapilhos soldados, que até então conservavam o único fardamento que receberam ao terem assentado praça (18). Rotos e descalços, eram êles que serviam freqùentemente nas armações à falta da mão de obra que a Fazenda Real deixava de pagar. Epoca houve em que a dívida para com os empregados alcançou a soma de 23:418\$590 (19).

Para agravar ainda mais os problemas relativos à pesca da baleia nessa ocasião, concorriam os navios estrangeiros promovendo a "pesca volante" ao cetáceo, em águas brasileiras (20).

Em 1819, por exemplo, apesar das proibições, devido à antiga tolerância dos Administradores das armações do Sul, os quais só cuidavam dos próprios interêsses, 20 navios estrangeiros dirigiramse àquêle litoral aportando na Itha de Santa Catarina. Promovida a pesca da baleia, iam os tripulantes frigir o toicinho no próprio pôsto, onde também contrabandeavam o azeite, além de outros artigos de comércio (21), explorando o povo e roubando gado.

Tal fato parece ter sido então habitual nas costas de São Pau1o, Santa Catarina e Rio Grande do Sul, causando grandes danos à pesca da baleia no Brasil (22). Só em 1819 entraram mais de vinte embarcações estrangeiras no pôrto da Ilha de Santa Catarina para pescar..., a saber:

Navio Baleana ....... Americano Cap. Edmund Gardner. Pesca

Bergantim President . " " William Clark ...."

Navio South America " "Joseph Earl ......" "

Navio Wilhelm ...... Holandês " H. Roozeboon ..... Comércio

\footnotetext{
ria para cobrir a despesa feita com a pesca e o dusteio das armações naquela ano, crdenados, etc. e ao mesmo tempo beneficiar a Fazenda Real.

(17). - L. A. Boiteux, op. cit., pág. 10.

(18). - Paulo José Miguel de Brito, op. cit., pág. 103, nota 9.

(19). - L. A. Boiteux, op. cit., pág. 10.

(20). - Biblioteca Nacional, Rio de Janeiro. Obras Raras. Documento II, 31, 1, 42. "Carta do Conde dos Arcos, datada do Rio de Janeiro a 28 de fevereiro de 1807, ao Capitão Tenente Pedro Antônio Nunes sôbre as providências a serem tomadas contra os navios estrangeiros que praticavam a pesca volante das baleies no litoral de Santa Catarina até o Rio da Prata". (Mantrserito Inédito).

Idem, "Carta do Conde dos Arcos datada do Rio de Janeiro a 20 de julho de 1820, a Tomas Antônio de Vila Nova Portugal, restituindo a representação e mais papéis dos Contratadores de Azeite de Peixe e afirmando duvidar do direito de ser possível tolher à fôrça de armas a pesca da baleia aos Americanos". (Manuscrito Inédito).

(21). - Idem, "De Antônio Mariano de Azevedo ao Rei, da Contadoria Geral da 2a. Repartição do Real Erário, a 7 de fevereiro de 1820, sôbre a Representação dos Administradores da Real Pescaria das Baleias do Rio de Janeiro, sôbre a desonestidade dos Administradores de Santa Catarina que toleravam a presença de Navios Estrangeiros nas costas do Brasil, permitindo que pescassem nas "suas lavras", que frigrissem o azeite no pôrto, que contrabandeassem, além de permitirem a fuga dos escravos do povo". (Manuscrito Inédito).

(22). - Idem, "Representação dos Administradores do Rio de Janeiro, assinada por Joaquim José de Siqueira, sôbre os danos causados à pesca da baleia no litoral sul, pelas embarcações estrangeiras, etc.". (Manuscrito Inédito). Com anexos.
} 


\begin{tabular}{|c|c|c|c|c|}
\hline ergantim Harrieth & Americano & Cap. & Nathaniel Hildreth & Pesca \\
\hline Bergantim Hiram .... & & & T. R. Gardner .... & \\
\hline Bergantim John. & Froncîs & , & Alfred Alley .. & 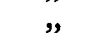 \\
\hline Navio Superior & Francês & $"$ & $\begin{array}{l}\text { Aubina Sevain } \\
\text { H. Penlham }\end{array}$ & \\
\hline $\begin{array}{l}\text { Navio Samuel . } \\
\text { Navio Milwood }\end{array}$ & Americano & $"$ & Joseph Wilcox & \\
\hline Navio Boston & " & " & F. R. Bernard & \\
\hline Navio Ruby. & $"$ & " & O. Ray ..... & \\
\hline Navio Neptuno & $"$ & " & Luther Smith & \\
\hline Navio Leo .... & " & " & H. Joy $\ldots \ldots$ & " \\
\hline Navio Massachusets .. & Francês & " & D. Baxter & \\
\hline Navio Victory ...... & Americano & , & S. Bunker & \\
\hline Navio South America & & " & Prose ... & \\
\hline Bergantinm Charlie. & Francês & " & W. Coily ... & " \\
\hline Navio Thomaz & Americano & " & Cabam Cothe & \\
\hline Navio George. & Francês & $"$ & J. Coster ... & " \\
\hline Navio Colombo & 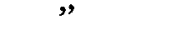 & " & Alexander Macy & $"$ \\
\hline Navio $F$ & mericano & " & & " \\
\hline
\end{tabular}

Em junho de 1816, as decadentes armações do Rio de Janeiro até Santa Catarina, passaram para a administração particular, pelo prazo de 12 anos, devendo a Corôa receber anualmente .... $21: 000 \$ 000$, até 1828 .

O inventário geral das armações, realizado em 1801, havia apurado a soma de 176:424\$797 e o de 1816 , realizado na ocasião do início da administração particular, importou em 111:663\$620, havendo um "deficit" de 64:761\$177. Em 1801, em tôdas as armações, trabalhavam 525 pessoas, em 1816 , as ocupadas com as atividades decorrentes da pesca da baleia chegavam a 333,

$$
\text { (...)"(..) 'em cujo número entravam } 84 \text { sem valor }
$$

(23). - Idem, "Atestado de José Maria Pinto Figueiredo, Tenente da Real Armada Capitão do pôrto desta Ilha (Santa Catarina) para S. Magestade..."; com a lista das embarcações; datado de 8 de outubro de 1819 . "Atestado de João Florêncio Jordão, Cavaleiro da Ordem de São Bento de Aviz, Sargento Mor do Estado Maior e Governador da Fortaleza de Santa Cruz da Barra do Norte da Ilha de Santa Catarina... 10 de outubro de 1819" sôbre o mesmo assunto (Manuscrito Inédito). Anexos ao documento anterior.

(24). - Pizarro e Araújo, op. cit., vol. 9.0, págs. 265 e 266 . Sôbre a administração particular, diz Lucas $A$. Boiteux, op. cit., págs. 10 e 11 , que foi levada a efeito perante a Junta Administrativa do Tesouro público, no Rio de Janeiro, pela firma Siqueira e Lima, que arrematou a administração da pesca da baleia do Rio de Janeiro, São Paulo e Santa Catarina, a começar em 1.0 de janeiro de 1827, por 21:000\$000 anuais, pelo prazo de doze anos. Os pagamentos seriam feitos aos quartéis para a Fazenda Real, “ (...) levando-se em conta o azeite gasto no Arsenal da Marinha, iluminação da cidade e das Repartições públicas ao preco de 120 réis a medida. Por êsse contrato as fábricas, utensílios e escravos das armações thes seriam entregues e lhes era dada a permissão para fundarem novos estabelecimentos". Essa administraçāo seria con siderada como real e seus administradores, como membros da Junta.

Siqueira e Lima formaram uma sociedade particular; Siqueira ficou com $4 / 8$ de interêsse e Lima com 1/8. Carneiro Viúva e Filhos com $2 / 8$ e Joaquim Antônio Alvares com $1 / 8$.

A sociedade não foi feliz devido à má administração levada a efeito pelos sócios diretores, terminando numa contenda. 
Cada medida de azeite, no início da administração régia, fôra taxada em 320 réis, tendo custado antes 140 réis. De 320 réis por medida o preço do azeite da baleia, para poder enfrentar a concorrência, baixou a 240 réis e a 200 réis.

"(...) servindo tais mudanças de motivo aos golpes fatais para a negociação, assim como contribuir para o prejuizo dos interêsses da Corôa, e dos serventuários" (25) .

Crescia a concorrência estrangeira. Faltava mão de obra. Aumentavam as despesas e minguavam os lucros. A pesca diminuia, na quantidade e na qualidade (26).

As oito pescarias realizadas de 1816 a 1819, apuraram 651 baleias, das quais à administração particular couberam 299, por terem pescado: 71 em 1816; 80 em 1817; 89 em 1818 e 59 em 1819 (27).

Em 1826 a armação de São Domingos da Vila Real da Praia Grande foi incorporada à Fazenda Nacional que a ađquiriu por 109:658\$690, terminando a administração particular até então exercida pela firma de Joaquim José de Siqueira \& Companhia, que a entregou ao depositário Francisco de Melo Magalhães.

Do inventário feito em 1831 dos bens da instalação, foi apurado o valor de $122: 212 \$ 340$.

Em 1833, passando a armação para o Ministério da Marinha, ali foi alojada uma cordoaria da qual, em meados do século — 1861 - só existiam as construções. No ano de 1834 os apetrechos da antiga fábrica de azeite foram vendidos pelo preço irrisório de $2: 511 \$ 880$. Em 1835, foi alugada ao Visconde de Albuquerque uma parte das dependências da antiga armação. Vinte anos depois era ela transformada em asilo de inválidos da Armada Brasileira, tendo-ihe sido anexada a área de uma chácara com ca-

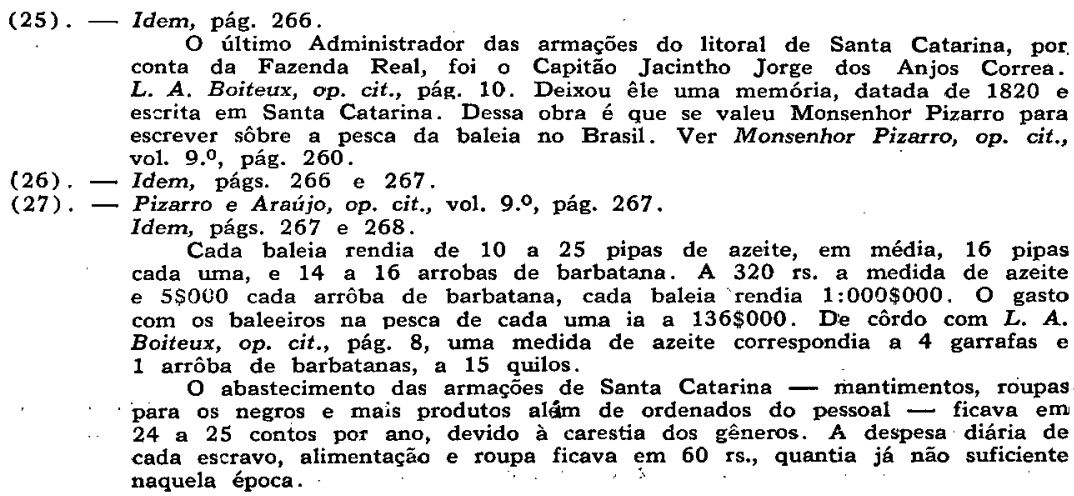
conta da Fazenda Real, foi o Capitão Jacintho Jorge dos Anjos Correa. L. A. Boitetrx, op. cit., pág. 10. Deixou êle uma memória datada de 1820 e escrita em Santa Catarina. Dessa obra é que se valeu Monsenhor Pizarro para escrever sôbre a pesca da baleia no Brasil. Ver Monsenhor Pizarro, op. cit,, vol. 9.0, pág. 260 .

(26). - Idem, págs. 266 e 267.

(27). - Pizarro e Araúfjo, op. cit., vol. 9.\%, pág. 267.

Idem, págs. 267 e 268.

Cada baleia rendia de 10 a 25 pipas de azeite, em média, 16 pipas cada uma, e 14 a 16 arrobas de barbatana. A 320 rs. a medida de azeite e 5\$000 cada arrôba de barbatana, cada baleia rendia 1:000\$000. O gasto com os baleeiros na pesca de cada uma ia a 136\$000. Die côrdo com $L$. $A$. Boiteux, op. cit., pág. 8, uma medida de azeite correspondia a 4 garrafas e 1 arrôba de barbatanas, a 15 quilos.

$O$ abastecimento das armaçōes de Santa Catarina - mantimentos, roupas para os negros e mais produtos altím de ordenados do pessoal - ficava em 24 a 25 contos por ano, devido à carestia dos gêneros. A despesa diária de cada escravo, alimentação e roupa ficava em $60 \mathrm{rs}$. , quantia já não suficiente naquela época. 
sa e terrenos de marinha existente no "Morro da Armação", adquirida por 20:000\$000 a José Luís Dias Diniz e sua mulher. Em 1866, - Ministério da Marinha aí instalava seu laboratório pirotécnico (28).

Quanto à armação da Bertioga, os bens que em 1789 foram avaliados em 18:440\$543, em 1835 o foram em 12:844\$200, excluídos escravos e incluindo as terras.

$\begin{array}{lr}\text { Bens de rais } \ldots \ldots \ldots \ldots \ldots \ldots & 10: 265 \$ 800 \\ \text { Bens moveis } \ldots \ldots \ldots \ldots \ldots \ldots & 134 \$ 360 \\ \text { Ferragens e utensilios } \ldots \ldots \ldots & 1: 744 \$ 040 \\ \text { Terras } \ldots \ldots \ldots \ldots \ldots \ldots \ldots \ldots & 700 \$ 000 \\ \\ \text { Total } \ldots \ldots \ldots \ldots \ldots & 12: 844 \$ 200\end{array}$

Ao apresentar estas cifras, das quais nos servimos para êste trabalho, disse Luís de França Almeida e Sá (29), referindo-se à desvalorização daqueles bens, de 1789 a 1835 ,

“Em 46 annos valeram menos $5: 596 \$ 343$, quando tudo augmentara de valor, simplesmente porque os bens da Nação regulão com os bens de sachristão!

E, cousa curiosa: Os Governos da Metropole e do Imperio matavam industrias, como a da pesca das baleias que frequentam os nossos mares, e o Governo da Republica tornou-se proteccionista de industrias para as quaes tudo vem do estrangeiro!

O que dirão os vindouros, quando estudarem o Brazil e encontrarem taes anomalias? Naturalmente que fomos crianças na Metropole, no Imperio e na Republical"

Isto foi escrito e assinado em: 10 de novembro de 1899! (30).

Quanto às armações de Santa Catarina, por decreto de 13 de novembro de 1827 foi estabelecida a venda de todos os pertencentes à nação, com exceção da de São Domingos em Niterói e das de Piedade e Lagoinha em Santa Catarina, consideradas necessárias ao serviço público.

Ninguém se interessando por aquela alienação, por Decreto de 30 de dezembro de 1828, foi à praça o arrendamento parcial de tôdas elas pelo prazo de um ano, devido ao fato de principiar a época da pesca da baleia em junho, afluindo muitos cetáceos ao litoral do Brasil até o mês de setembro.

As armações de Santa Catarina, então administradas por Antônio Mendes de Carvalho, passaram para vários depositários, inclusive a de Lagoinha:

\footnotetext{
(28). - Luís de França Almeida e Sá, loc. cit., págs. 186 e 187.

(29). - Loc. cit., pág. 189. Era o Autor sócio efetivo do Instituto Histórico e Geográfico Brasileiro e, na época, servia, em comissão, na Secção de Tombamento dos Próprios Nacionais.

(30). - Luís de França Almeida e Sá, op. cit., págs. 189 e 192.
} 
Armação da Piedade - Major Silvestre José dos Passos.

Armação de. Itapocoróia e seu suplemento da Ilha da Graça - José Feliciano de Proença.

Armação de Garopaba e seu suplemento, Imbituba - Cap. João Xavier de Souza.

Armação da Lagoinha - Cap. Tomás Cardoso da Costa .

Haviam sido avaliados em 1826:

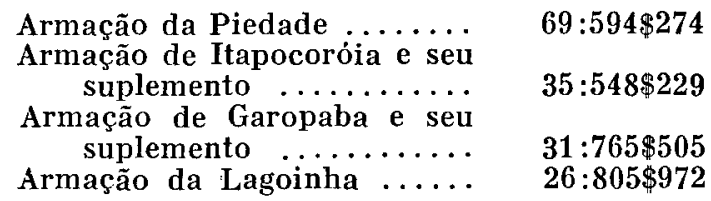

(31).

Ainda sôbre as armações de Santa Catarina, de acôrdo com os dados extraídos da "Secção de Tombamento dos Próprios Nacionais" por Luís de França Almeida e Sá, em 1899 (32):

- Da armação de Piedade, pelos anos de 1847 e 1848 , por determinação do govêrno provincial (33), quase a maior parte dos terrenos foi cedida a colonos alemães, sendo mantida apenas uma área reduzida, com 96 metros de frente e 150 de fundo. Na última década do século XIX, dela restavam apenas um armazém e a Capela rodeada de ruínas...

- Sôbre as armações de Garopaba-Imbituba, o capitão Manuel Francisco de Souza Medeiros que as arrematara em 1837, deixara de pagar em 1841 uma letra relativa àquêle negócio.

Ao terminar o século XIX, nem estas, nem a armação de Lagoinha existiam, " (...) não existiam mais essas bem montadas propriedades que, em 1826, custaram à Nação $94: 119 \$ 906$ (..)" e que ao findar o século, sem dúvilda “( (..) valeriam... vinte vêzes mais daquele custo!

E assim tem-se cuidado do Patrimônio do Brasil!

Não admira quando êste deve atingir a um milhão de contos e nada produz!" "Tudo isto bem demonstra - quanto hão descurado da fortuna pública os Governos da Metrópole, ido Império e da República (...)" (34).

Lucas A. Boiteux, no seu trabalho sôbre a pesca da baleia em Santa Catarina (35), menciona uma tentativa para o reerguimento daquela atividade na região, em 1864. Diz que Antônio Mâncio da Costa e Joaquim Fernandes Capela estabeleceram uma ar-

\footnotetext{
(31). - ILuís de França Almeida e Sá, op. cit.p págs. 190 e 191.

(32). - Loc. cit., pág. 191.

(33). - L. A. Boiteux, op. cit., pág. 12. Nessa ocasião as águas brasileiras eram constantemente visitadas por baleeiros norte-americanos que muito contribuiram para a diminuição dos cetáceos. Em 1841, navegavam 600 embarcações com 13.000 homens. Idem, ibidem.

(34). - Luís de França Almeida e Sá, op. cit., págs. 191, 192.
} 
mação nos Ganchos e que em setembro daquela data conseguiram .pescar uma baleia e um baleote... O empreendimento frustrou-se.

Nas ptimeiras décadas do século XX, das armações de baleias de Santa Catarina só restavam

" (...) ruinas informes, carcassas desmanteladas... a attestarem a grandeza e valor de uma industria assás lucrativa, que, em passados tempos, o mar catharinense immensamente piscoso proporcionava e que o tempo e os homens deixaram criminosamente desapparecer" (36).

A pesca $e$ a industrialização da baleia no Brasil arrastaram-se ainda até início do século $\mathbf{X X}$, èm Salvador e Caravelas, na $\mathrm{Ba}$ hia. As técnicas não evoluiram, subsistindo, até então, os mesmos processos arcaicos e rotineiros dos tempos coloniais desde há muito ultrapassados e em desuso na pesca da baleia (37). Com êles nascera e com êles morria a indústria baleeira no Brasil e, na mesma região, na Bahia!

\section{CONSIDERAÇÕES FINAIS.}

A pesca da baleia foi uma das mais curiosas atividades econômicas do Brasil Colonial. Deu origem a importante indústria de óleo e outros derivados do cetáceo e se desenvolveu no litoral das Capitanias da Bahia, do Rio de Janeiro, de São Paulo e de Santa Catarina, durante os séculos XVII e XVIII, extinguindo-se pràticamente no século XIX. Tão importante foi, que chegou a ser monopólio da Corôa portuguêsa. Liqüidaram-na a imprevidência e o descuido dos que a dirigiram e exploraram, a concorrência estrangeira, a diminuição do número dos mamíferos em águas brasileiras e por fim, o desenvolvimento de novás técnicas de iluminação advindas do emprêgo do gás, do petróleo e da eletricidade.

Dessa importante indústria do passado que iluminou o Brasil Colonial, alimentou os escravos, supriu as naus de comércio, sustentou durante dois séculos um monopólio régio, abasteceu outras inđústrias, como a do sabão, do enxôfre, do alcatrão, de couros e tecidos, restam-nos hoje a documentação dos arquivos de Portugal e do Brasil, informações de cronistas e viajantes e, escassas ruínas de uma cu outra armação, que resistiram à ação destruidora do tempo e do homem.

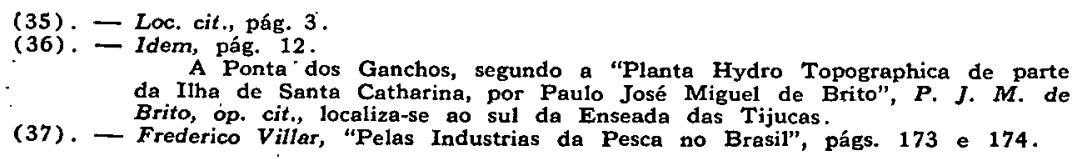
da Itha de Santa Catharina, por Paulo José Miguel de Brito", $P . J . M$. de Brito, op. cit., localiza-se ao sul da Enseada das Tijucas.

(37). - Frederico Villar, "Pelas Industrias da Pesca no Brasil", págs. 173 e 174. 
Percorrendo periòdicamente o Atlântico brasileiro, a baleia foi aí encontrada desde os primórdios da descoberta e da colonização do Brasil.

As primeiras informaçōes sôbre o cetáceo datam dos meados do século XVI. Não tratam da pesca, mencionam apenas o granae número de baleias e o aproveitamento dos espécimens que ao se aproximarem demasiadamente da costa, encalhavam na areia das praias, permanecendo em sêco e aí morrendo sufocadas pelo próprio pêso, o que não ocorre no seu meio natural, onde podem flutuar. Quando isto sucedia as populações litorâneas serviam-se da carne dêsses animais para a alimentação e do toicinho, de que extraiam o óleo para iluminação, além. de recolherem o âmbar lançado às praias pelas ondas. Era praticado, então, o que poderia denominar-se a verdadeira "coleta" dos produtos da baleia. Essa pesca efetuada a partir do início do século XVII, parece não ter sido praticada pelo homem, no Brasil, antes daquela data. Tanto isto é verdade que os cronistas se referem à abundância de baleias que não encontravam quem as pescasse, à falta de óleo para iluminação e outras inúmeras aplicações e à introdução daquele tipo de economia na Bahia, por biscainhos, nos primeiros anos do seiscentismo.

Algum tempc depois eram erguidas as primeiras armações do Brasil.

Da Bahia, a pesca da baleia se estendeu ao Rio de Janeiro, ainda na primeira metade do século XVII. Antes de iniciar-se o XVIII, atingiu o litoral paulista. Alargando-se ainda mais para o sul, em menos de cinqüenta anos ocupou as costas de Santa Catarina onde foram construídas armações até os fins do século XVIII e também no seguinte.

Portugal, desde 1580 sob o domínio da casa de Castela, sofreu certamente a orientação político-econômica filipina no desenvolvimento da pesca da baleia, no Brasil, introduzida pelos biscainhos trazidos da Europa pelo governador geral, D. Diogo Botelho, em 1602, bem como no estabelecimento do monopólio. Pesca e monopólio foram, assim, concomitantes. A Corôa castelhana, tão propensa a privilégios, arrendamentos e contratos, teria reforçado o monopólio português em vários setores, de modo que a instalação da indústria baleeira no Brasil veio a criar mais uma fonte de renda para a Fazenda Real.

Na primeira década do século XVII, ainda limitada ao Recôncavo baiano, a pesca e a indústria da baleia já eram, portanto, exclusividade régia. Na mesma época em que surgiam as primeiras armações, eram estabelecidos os primeiros contratos de ar- 
rendamento, que seguiram a trajetória daqueles postos baleeiros, acompanhando-os também no sul da Colônia.

Aqui, antes de 1743, foram arrematados, em separado, os contratos do Rio de Janeiro, da Ilha de São Sebastião, de Santos e São Paulo e da Ilha de Santa Catarina. Daquela data em diante, visando unidade de ação e melhores lucros, procuraram os Contratadores arrendá-los conjuntamente. Em 1765 foram todos os contratos, inclusive o da Bahia, incorporados num privilégio único. $\mathrm{E}$ assim se mantiveram até 1801 , quando a Corôa portuguêsa extinguiu o real monopólio da pesca da baleia no Brasil .

Esse monoṕ́lio bem como outros praticados na época pela Metrópole, tais como os do sal, couro, tabaco ou diamante, foi um reflexo do sistema de govêrno absoluto impregnado de concepções que favoreciam uma ampla intervenção do Estado na economia ruacional. Constituiu, portanto, mais um exemplo dentre as múltiplas manifestações da economia dirigida no setor da produção e do comércio do Reino e suas colônias.

Obra do domínio dos Filipes em Portugal, o monopólio da pesca da baleia no Brasil foi mantido depois da Restauração, pela Corôa portuguêsa, devido às dificuldades financeiras, às constantes necessidades de rendimentos que permitissem enfrentar os problemas da política interna e externa do Reino. E continuou por todos os séculos XVII e XVIII a contribuir com indispensáveis proventos para a Fazenda Real, cobrindo despesas na Metrópole e na Colônia.

O' período do apogeu do monopólio no Portugal do século XVIII correspondeu à época de Pombal, de 1750 a 1777, época de refôrço de exclusividades comerciais e de grandes privilégios concedidos à burguesia mercantil portuguêsa. Esta foi a classe favorecida pela política do monopólio, que recebia em troca a sua cooperação interessada no fortalecimento do Estado.

A administração pombalina, um dos exemplos mais evidentes da intervenção do Estado absolutista no movimento comercial da nação, apoiou e incentivou intensamente o monopólio. Para tanto, requeria-se um Estado forte, o que realmente foi empreendido e realizado por Pombal, em decorrência da sua política de fortalecimento do poder real que teve seu ponto de apôio justamente na burguesia mercantil. Desta sairam muitos Contratadores da pesca da baleia do Brasil Colonial, tais como os Quintela, Inácio Pedro e Joaquim Pedro, por exemplo.

Outros fatôres que no século XVIII teriam concorrido para consolidar o sistema do monopólio no Brasil, entre êstes, naturalmente, o da pesca da baleia, foram a necessidade de recursos para se enfrentarem problemas advindos da reconstrução de Lisboa ar- 
rasada pelo terremoto de 1 de novembro de 1755; as lutas com a Espanha na Penírsula e na América, que contribuiram no sentido de que a Real Fazenda não dispensasse seus menores recursos e a crise de produção brasileira resultante do declínio da mineração. A necessidade de numerário somada à orientação política do primeiro ministro de $\mathbf{D}$. José, favoreceram portanto o incremento ao real monopólio da pesca da baleia no Brasil.

Quanto ao arrendamento dos privilégios de exploração econômica colonial, o rei, senhor do monopólio, como um verdadeiro negociante, tornava temporàriamente sócios da Fazenda Real, mediante o estabelecimento de contratos, comerciantes do Brasil e de Portugal. Era êste um dos aspectos da velha prática de arrendamento das rendas reais, segundo o qual, o soberano as recebia adiantadamente, com os respectivos lucros líqüidos para gasto imediato e solução de aperturas financeiras. Será desnecessário dizer que, neste negócio, a Corôa se resguardava com tôdas as garantias possíveis. Comprometia-se, por exemplo, a manter o consumo português do óleo de baleia produzido no Brasil, proibindo a importação do artigo de outros produtores. Quer isto dizer que os Contratadores, além da exclusividade de fornecimento do azeite do cetáceo para todo o Brasil, teriam o monopólio da exportação daquela matéria prima para o mercado português. Isso, porém, só no caso de ser enviada em quantidade suficiente e a um preço determinado. Do contrário a Corôa promoveria a importação do produto.

O monopólio da pesca da baleia no Atlântico brasileiro, devido à importância dessa atividade econômica no período colonial, constituiu, portanto, um dos muitos exemplos do sistema de privilégio comercial adotado pela Corôa lusitana em relação ao Brasil, e foi, sem dúvida, uma das múltiplas formas usadas pela Metró pole para usufruir as possibilidades econômicas de sua Colônia. Genuína decorrência da orientação colonialista que tantas vêzes chegou a descambar para a opressão.

Quanto à supressão do real monopólio da pesca da baleia no Brasil Colonial, pode-se dizer que resultou: $10^{\circ}$ ) $\mathrm{Da}$ decadência da mesma pesca, motivada pela diminuição dos cetáceos nas costas brasileiras, expulsos pela perseguição sem tréguas que thes era movida; da má orientação da pesca praticada segundo princípios de uma economia destrutiva e alheios a técnicas racionais; das falhas e desleixos cometidos no setor industrial do aproveitamento do toicinho para a obtenção e conservação do azeite, bem como o aproveitamento de outros derivados da baleia. $2 .^{\circ}$ ) $\mathrm{Da}$ concorrência movida no Atlântico pelos estrangeiros melhor aparelhados tècnicamente. $3 .^{\circ}$ ) Do próprio monopólio que, impedindo a concorrência, conseqüientemente impediu também o aperfeiçoamento 
dos métodos e técnicas da pesca e da indústria baleeira no Brasil Colonial. A atividade sufocada pelo monopólio, não evoluindo, estagnou-se. Não foi suficiente o incremento dado à pesca e à indústria, pela administração dos Quintela. $4 .^{\circ}$ ) $\mathrm{Da}$ influência de José Bonifácio através da "Memória sôbre a pesca das baleias, e extração do seu Azeite com algumas reflexões a respeito das nossas pescarias", publicada nas "Memórias Econômicas da Real Academia de Ciências de Lisboa", em 1790, com o objetivo de demonstrar a importância da liberdade da pesca da baleia no Brasil e do aproveitamento econômico do cetáceo por uma indústria melhor orientada, mais racional e portanto mais eficiente. Era necessário o "(...) aguilhão da emulação e concorrência (...)", dissera o Andrada. $5^{\circ}$ ) Do esfôrço da Academia Real das Ciências de Lisboa que liderou a renovação econômica e cultural de Portugal na época de D. Maria I. $6^{\circ}$ ) $\mathrm{Da}$ orientação político-econômica do reinado de D. Maria I, visando a promover e ampliar a produção dos gêneros do Brasil para o comércio metropolitano em substituição à mineração já em declínio.

Infelizmente, era tarde demais. A pesca e a indústria da baleia não se reergueram.

Durante mais de dois séculos, centenas de pessoas desenvolveram as mais variadas atividades em tôrno da pesca e da inaústria baleeira, no Brasil Colonial: muitos negociantes brasileiros e portuguêsess, Contratadores do monopólio e fundadores de armações; administradores e mais funcionários dos contratos; pessoal das armações, assalariados e escravos, feitores, mestres, técnicos no esquartejamento da baleia e na fabricação do azeite e mais produtos derivados, pescadores, remeiros, timoneiros e arpoadores, êstes últimos, elementos decisivos no bom êxito e nos lucros da pesca da baleia; vendedores ambulantes e quitandeiras. Em resumo, bran$\cos$ - portuguêses, brasileiros e até estrangeiros - negros e mestiços - êstes geralmente constituiam a escravaria das armações -; todos viveram e atuaram parcial ou integralmente, ligados às atividades da indústria da baleia, ou da pesca, que em certos períodos do ano e em alguns pontos do litoral brasileiro atraia centenas de espectadores, que iam apreciar os emocionantes episódios da luta de morte entre os pescadores e os cetáceos.

Aquêles que se dedicavam pròpriamente à pesca da baleia entre nós parecem ter sido em geral pessoas rudes e da mais baixa categoria social. Desordeiros por índole, entregavam-se freqüentemente à bebida e às arruaças. Tidos por indisciplinados e ociosos, quando se obstinavam a não ir para as armações, eram presos e levados à fôrça. Outros, criminosos, condenados a trabalhos públicos 
forçados, ou "escravos da pena", em ferros e sob constante vigilância, constituiram muitas vêzes ameaça à vida dos feitores.

Devido aos grandes e inúmeros riscos decorrentes da pesca e dos pesados trabalhos da indústria baleeira, era problemática a arregimentação de mão de obra melhor selecionada para o exercício daquelas atividades. Contratadores, administradores e feitores aproveitavam os escravos para a fabricação do óleo. $O$ escravo custava dinheiro, representava capital empatado, não convindo, portanto, arriscá-lo sempre nas pescarias. Os assalariados e os "escravos da pena", em caso de acidente, não representariam prejuízo material para o contrato. Eis porque eram buscados e conduzidos à fôrça, pois muitos relutavam em ir à pesca e os Contratadores e administradores tinham autoridade suficiente para coagí-los a êsse serviço.

Os problemas relativos à mão de obra empregada nas armações também concorreram sem dúvida para a decadência da indústria baleeira do Brasil Colonial. Isto, sem falar nos feitores, ho mens ignorantes e retrógrados e nos próprios administradores que empregavam um número de homens por vêzes desnecessário, e em muitos casos sem prática ou conhecimento da técnica de pesca.

Tomaram a dianteira os estrangeiros, inglêses e norte-americanos, tècnicamente mais evoluídos, e que, em suas embarcações baleeiras, vinham ao Atlântico sul pescar os cetáceos, estabelecendo concorrência vitoriosa em relação às armações brasileiras.

Quanto às armações ou núcleos baleeiros do Brasil Colonial, contribuiram notàvelmente durante os séculos XVII e XVIII para a ocupação de amplas áreas do litoral brasileiro, desde o Recôncavo baiano até Santa Catarina, dando origem à intensa atividade humana que girou em tôrno da pesca e da indústria dos produtos derivados do cetáceo. Provam-no os inventários das armações e outros documentos da época.

Concentraram-se as armações orientadas pelo sistema do monopólio, em duas regiões: uma, no litoral norte, centralizada no Recôncavo baiano; outra, ao sul, ou seja, ao longo da costa fluminense, paulista e catarinense, onde se reuniu o maior número de armações, que sobrepujaram indùstrialmente as do Recôncavo, pelas proporções da pesca e do aproveitamento econômico da baleia.

Da primeira região, a pesca e a indústria baleeiras foram levadas à segunda, onde surgiram várias armações, no decorrer dos séculos XVII e XVIII, fundadas pelos Contratadores, os quais se comprometiam a erguer os estabelecimentos com capitais próprios, suprí-los de tudo quanto fôsse preciso e depois de explorá-los durante certo periodo, entregá-los à Fazenda Real para novo arrendamento. Tão compensadores deveriam ser os lucros advindos dos 
contratos que certamente cobriam muito vantajosamente as despesas resultantes do estabelecimento de uma armação.

$O$ fato de se fundarem as armações sempre para o sul é explicável pela presença, nessas zonas, de águas mais férteis em baleias de boa qualidade.

Com o correr do tempo, já na segunda metade do século XVII, a região do Recôncavo deixou de oferecer as vantagens que proporcionara à época em que lá fôra introduzida a pesca; devido, certamente ao deslocamento das baleias para o sul, acossadas pelo homem em sua faina destruidora.

O estabelecimento de armações no litoral sul do Brasil CoIonial teria, sem dúvida, prejudicado ainda mais a pesca baiana pelo fato de impedir que maior número de baleias afluisse até às águas do Recôncavo, em suas migrações periódicas em busca de mares mais tépidos para a reprodução e fecundação.

Com tudo isso sofriam os Contratadores da Bahia as conseqüências de uma pesca frustrada, alcançando grandes prejuízos e tendo sido alguns executados mesmo pela Fazenda Real. Chegou a tornar-se difícil a arrematação dos contratos da pesca na Bahia. Uma grande queda nos preços verificou-se nas últimas décadas do século XVII.

Em compensação desenvolveu-se a pesca ao sul no século imediato, aumentando e prosperando as armações locais. E' possivel que dêsse fato tenha contribuído para a unificação de tôdas as armações do Brasil, sob contrato único, em 1765, capaz de permitir o reerguimento eventual das que estivessem em decadência.

Com efeito, graças ao arrendamento da pesca da baleia naquele ano, por Inácio Pedro Quintela, puderam ser então aplicados grandes capitais em escravos e apetrechos necessários ao amparo à indústria baleeira no Brasil, reconstrução e ampliação das armações de todo o litoral e erguimento de outras na costa catarinense. Foi a época do grande incremento à pesca e à industrialização da baleia, devido à proteção do marquês de Pombal ao monopólio português. Foi quando as armações conheceram e alojaram a indústria do espermacete até então não aproveitado pelo desconhecimento da técnica apropriada à obtenção e preparo do produto.

Até 1789, mais ou menos, prolongou-se o período de desenvolvimento das armações, principalmente do litoral catarinense, com o incremento à pesca e à indústria baleeiras promovido pelos contratos dos Quintela, Inácio Pedro e Joaquim Pedro, arrematados respectivamente em 1765 e 1777 . O contrato novamente arrematado em 1789 por Joaquim Pedro Quintela não teve o mesmo êxito dos antecedentes, anunciando o próximo declínio das arma- 
ções do Brasil. E' que o número de mamíferos escasseava provacando a diminuição da pesca. Além disso, apesar do incremento dos Quintela à indústria baleeira na segunda metade do século XVIII, predominaram nas armações métodos falhos, antiqüados e rotineiros no setor técnico da pesca e da obtenção do azeite.

Com o declínio das armações do Brasil em 1789, perdiam elas o caráter exclusivista da pesca e da industrialização da baleia. A Corôa portuguêsa diante da concorrência estrangeira e da diminuição dos mamíferos em águas brasileiras, era obrigada a permitir a pesca e a obtenção do azeite e das barbatanas em alto mar, bem como a construção de armações em qualquer parte do Reino e colônias. Preparava a supressão do monopólio decretada, por fim, em 1801.

Finda a exclusividade régia da indústria da baleia no Brasil, a Fazenda Real passou a administrar as armações, já que ninguém se interessara por adquirí-las, com exceção das de Itaparica e Itapoã. Essa administração, entretanto, descuidou-se por completo da manutenção daqueles postos baleeiros, acentuando-se a sua decadência, para o que muito colaborou a concorrência dos navios estrangeiros à busca de baleias em águas atlânticas sul-americanas. Chegaram os tripulantes ao cúmulo de se aproveitarem das instalações e dos apetrechos das armações brasileiras do litoral sul, para a fritura do toicinho do cetáceo, causando grandes prejuízos à pesca.

A administração particular $e$ o arrendamento também não salvaram da ruína as armações estabelecidas entre o Rio de Janeiro e Santa Catarina.

Em fins do século XIX, muitas já haviam desaparecido.

Hoje, das armações de pesca da baleia restam algumas poucas e esparsas ruínas no litoral brasileiro, a resistirem teimosamente à ação do tempo e a lembrar antigos núcleos de importante indústria, cujas atividades, muitas vêzes assistidas passivamente pelas populações coloniais, não thes melhoravam as condições de vida e de comércio... Populações que, espontâneamente ou coagidas, contribuiram com elemento humano para os trabalhos.

Quanto ao aproveitamento dos produtos do cetáceo, os mais importantes para o Brasil Colonial foram a matéria graxa fornecedora de óleo e a carne. O óleo tornou-se artigo de primeira necessidade porque dêle dependeu a iluminação de centenas de habitações, "fábricas" e "oficinas". Combinado com a cal, o óleo de baleia produz um composto, o oleato de cálcio, que foi empregado como excelente e duradouro material de construção, argamassa consistente e inatacável pela ação corrosiva das águas da chuva. 

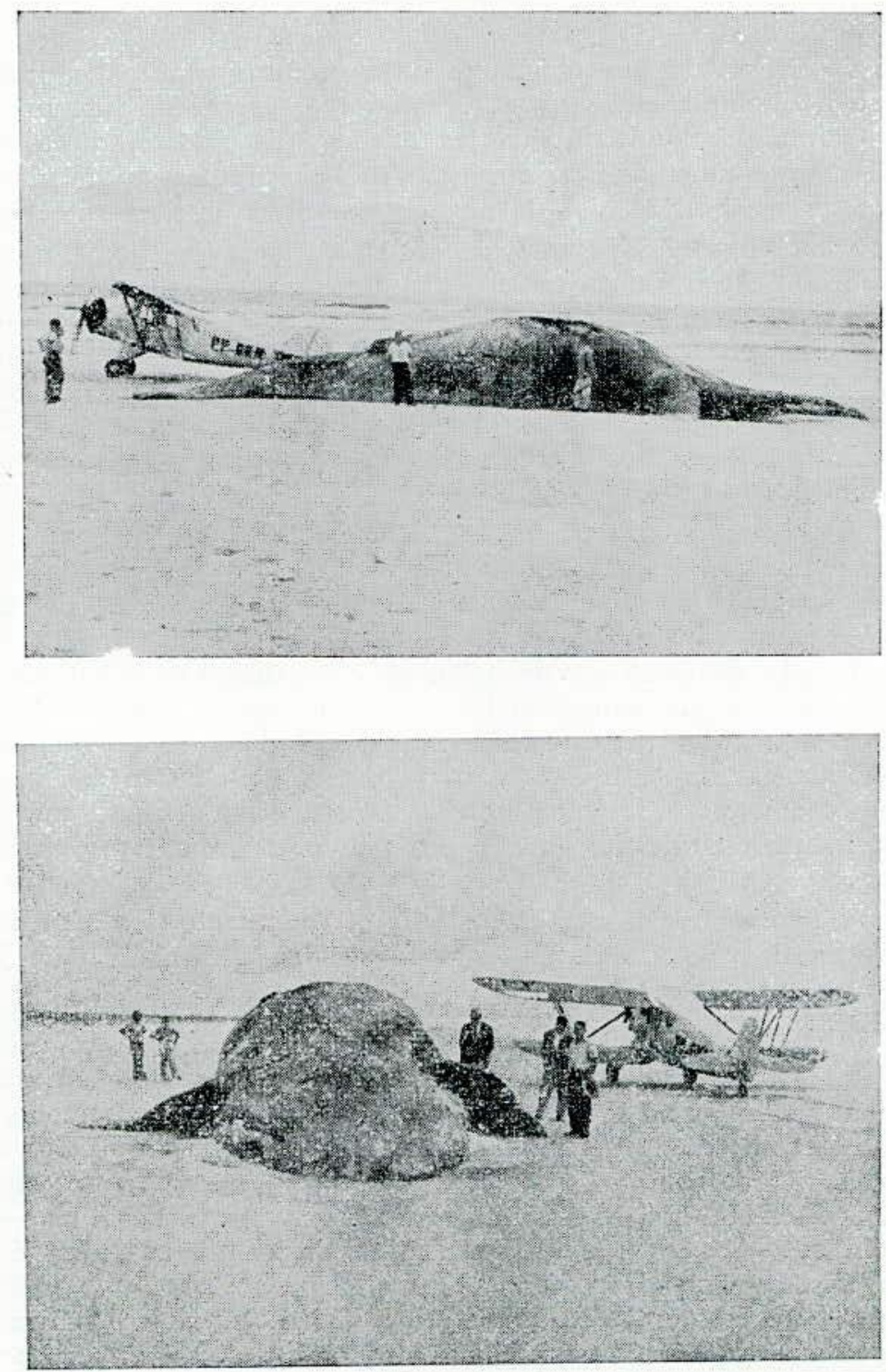

Fig. 3. - Baleia encalhada em junho de 1949 na Praia Deserta, no litoral paranaense, setenta quilômetros mais ou menos ao sul de Cananéia. Possuindo 18 metros de comprimento, o animal fotografado apresenta-se de ventre voltado para cima e com o dorso completamente enterrado na areia. O que vemos são sîmente dois terços do seu corpo já em início de decomposição. Daí a dificuidade para uma classificação mais completa dêsse cetáceo do grupo dos "mistacocetos". Pareze ser um exemplar da familia dos "balaenideos", ou "rightwhiles". $\mathrm{Na}$ opinião do Prof. W. Besward, diretor do Instituto Oceanográfico de São Paulo e autor das fotografias, seria, entretanto uma "Balaenoptera musculus", exemplar de granterideos", ou "rorquals". (Fotografias gentilmente cedidas pelo Instituto Oceanográfico terídeos", ou rorquals". (Fotografias gentilmente cedidas pelo Instituto Oceanográfico 
Serviu, ainda, o óleo, no preparo de couros e na calafetação de embarcações tal a sua ação altamente impermeabilizante. A carne, fresca ou salgada, teve consumo entre os escravos e as populações do litoral, os pobres principalmente.

Em relação a Portugal, onde as indústrias da época tiveram a ampla liberdade que o Brasil não conheceu, o óleo encontrou as mais variadas aplicações, servindo para o fabrico de sabão, tintas, cordoaria, tecidos, refinação do enxôfre e preparo de alcatrão. A carne era sustento das tripulações nas embarcações que serviam no tráfico marítimo comercial. Âmbar e barbatanas e, sem dúvida, os valiosos dentes de puro marfim dos cachalotes circularam no comércio metropolitano.

O aproveitamento do espermacete só foi praticado no Brasil na segunda metade do século XVIII, na época dos Quintela, os quais procurando incrementar a indústria da baleia em benefício do monopólio, para cá enviaram técnicos estrangeiros especialistas no assunto.

A indústria da baleia foi uma das que Portugal permitiu no Brasil Colonial. Apesar do impulso que lhe conferiu a época pom-

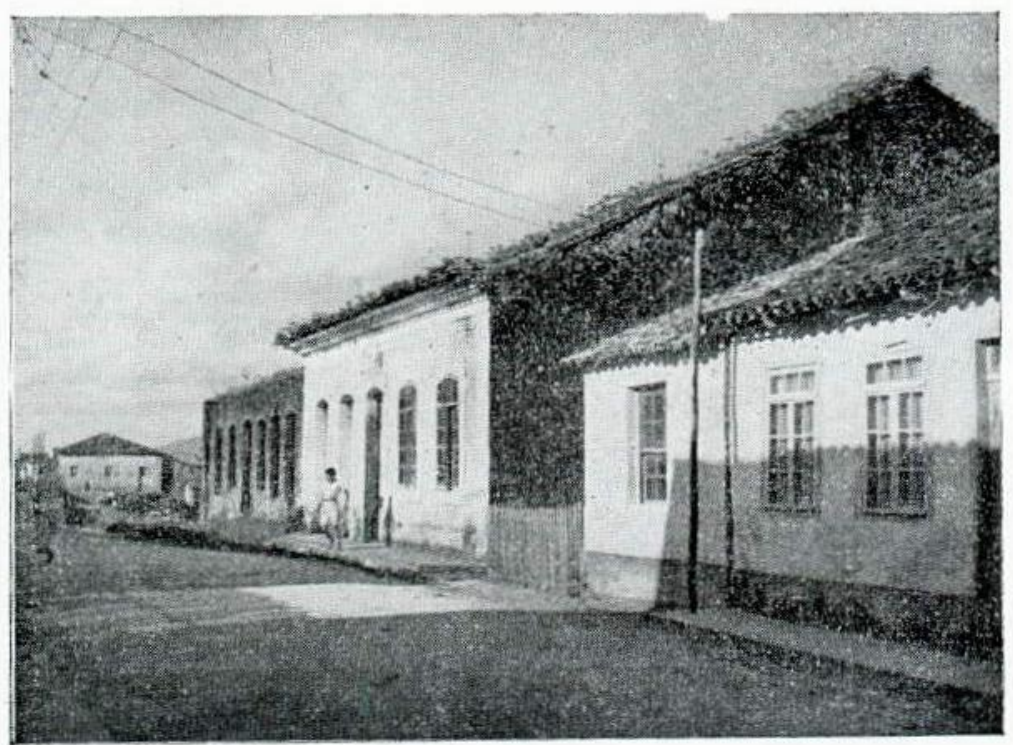

Fig. 4. - As duas casas que figuram no segundo plano da fotografia localzam-se na rua principal de Cananéia, no litoral paulista. São antigas e, segundo o prof. W. Besnard, diretor do Instituto Oceanográfico de São Paulo, que as examinou, as paredes foram construidas com pedras unidas com argamassa feita de cal, areia, água e óleo de baleia. (Fotografia tirada em 1949, pelo prof. W. Besnard e gentilmente oferecida pelo Autor). 
balina, o monopólio parece ter-1he entravado um maior avanço técnico, o que constituiu, tempos depois, um dos fatôres de sua decadência.
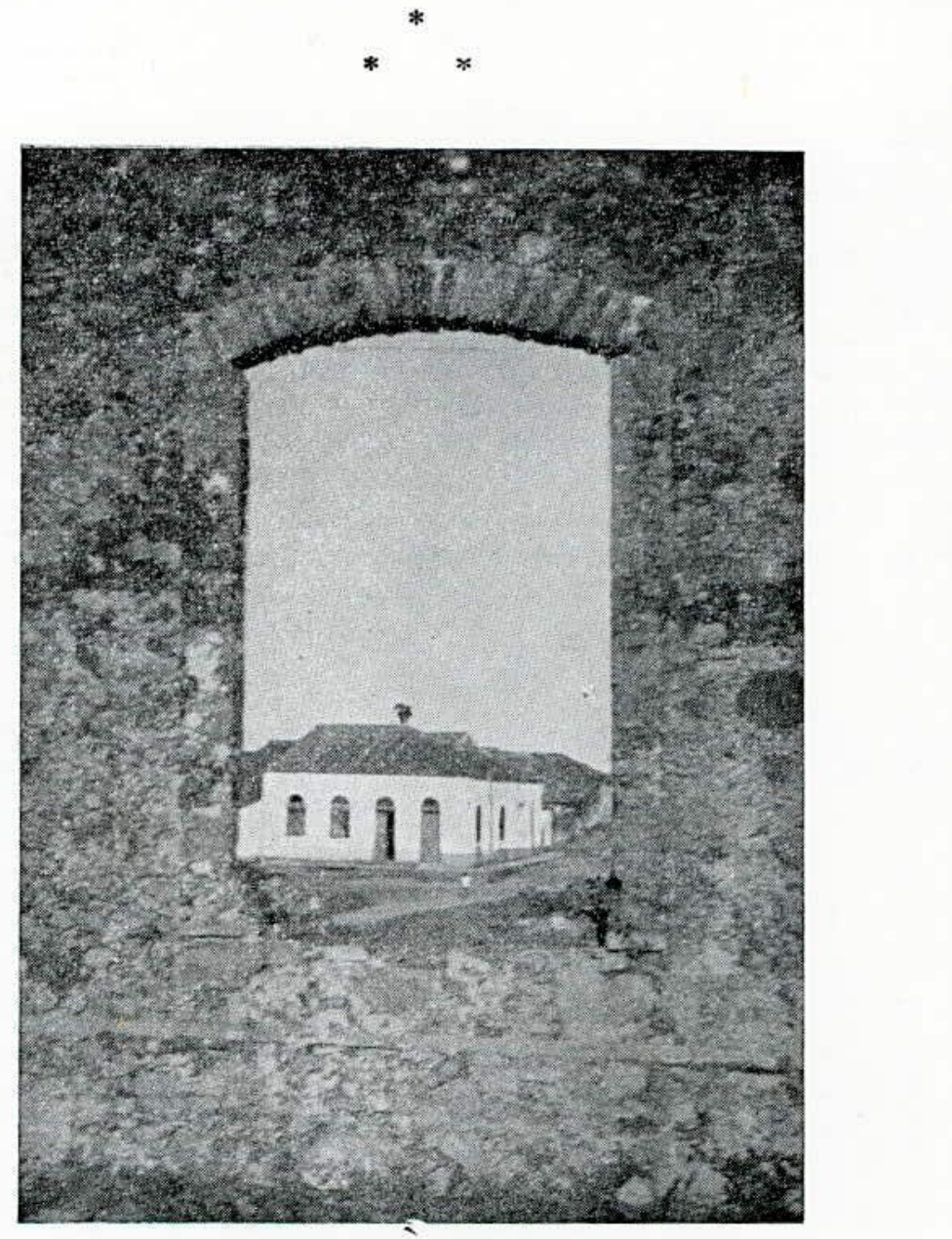

Fig. 5. - Vão de janela em uma parede construída de pedra e argamassa feita de cal, areia, água e óleo de baleia. Fotografia do interior de uma das antigas construções de Cananéia e cuja parte externa é vista no retrato acima. Oferecida pelo prof. W. Besnard que nos deu a seguinte informação: o óleo de baleia, matéria graxa animal combinada com a cal cristalizada pela ação da água, dá origem ao oleato de ḉlcio, excelente e duradouro material de construção, inatacável pela água da chuva que é bastante corrosiva. Quanto à cal, é obtida de ostreiras e sambaquis. Foi dêsses depósitos que o homem da época colonial extraiu a cal necessária para as construções, certamente por meio do processo primitivo ainda praticado atualmente pelos caiçaras em nosso litoral e cuja fotografia apresentamos adiante. (Fotografia tirada em 1949 pelo prof. W. Besnard e atenciosamente oferecida pelo Autor). 
Atualmente, entre junho e setembro, fugindo aos rigores do inverno antártico, emigram as baleias buscando águas tropicais para a procriação. Ao navegarem pelas costas do Brasil, muitas, ainda hoje, encalham e sucumbem nas praias, servindo seus corpos, grandes e inertes, de motivo de atração para o povo que, em geral ignora a importante indústria que o cetáceo alimentou em nosso passado colorial e o fato de que baleia não é peixe...

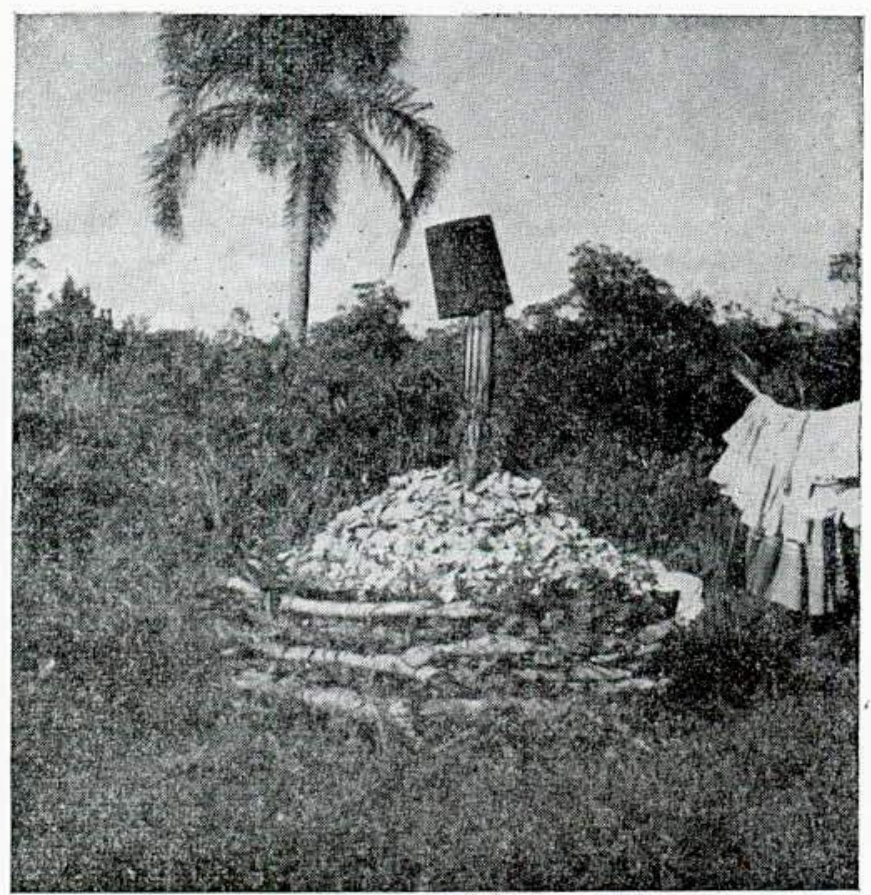

Fig. 6. - Curioso tipo de caieira construída pelos caiçaras da região de Cananéia. Cascas de ostras colhidas em ostreiras próximas e empilhadas sôbre galhos e ramos secos de uma fogueira. - Tosco e rudimentar processo de obtençáo da cal, empregado desde os tempos coloniais, na falta do produto que, ou era importado do Reino ou extraido de ostreiras ou sambaquis do litoral brasileiro. Unida à água, areia e óleo de baleia, a cal era produto indispensável à constituiçẫo da argamassa destinada aos muros e paredes, pela sua ação sôbre o óleo combinando-se com êle, para a formação do oleato de cálcio. (Fotografia de A. N. Ab'Sáber e fornecida pelo "Instituto Oceanográfico de São Paulo", por nimia gentileza do prof. W. Besnard). 

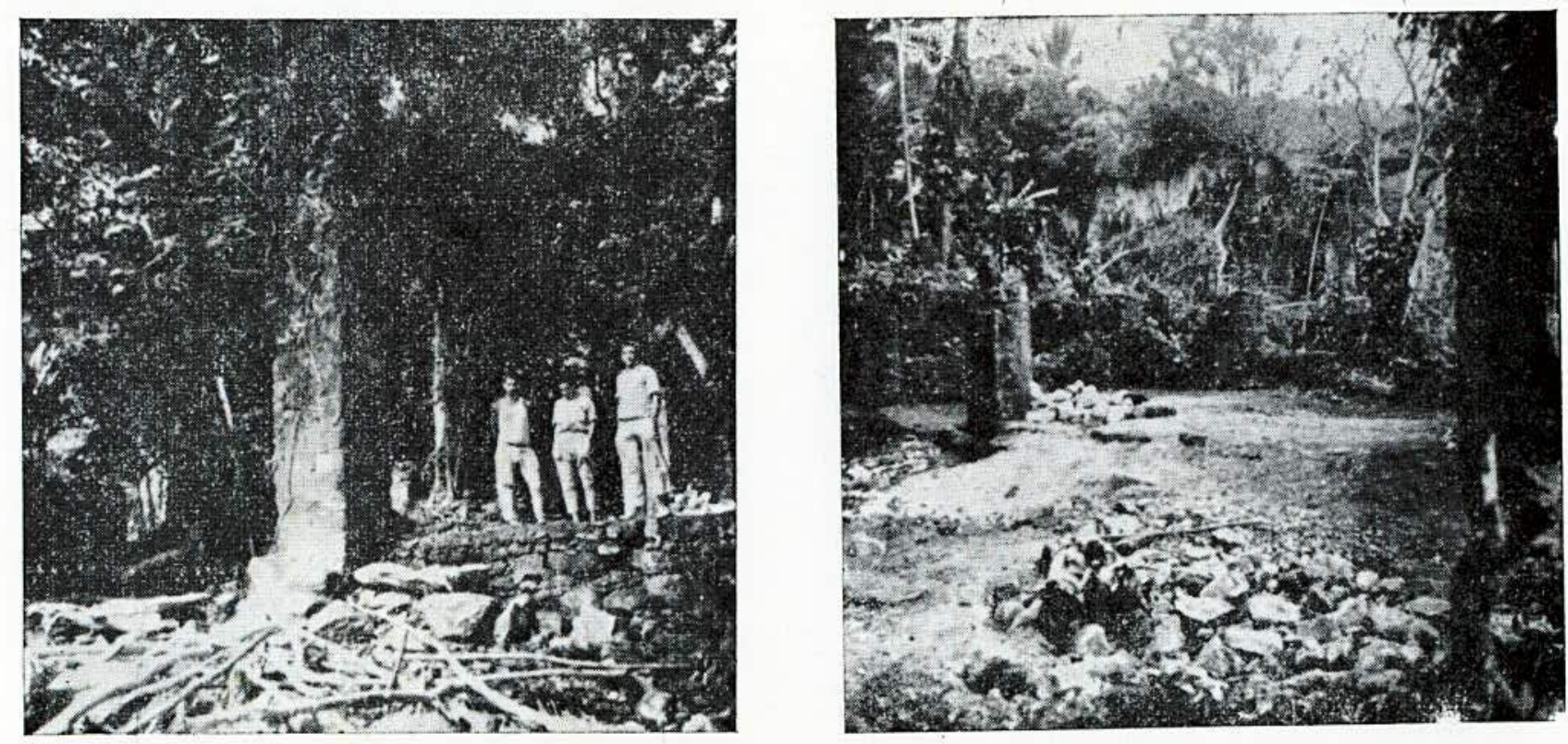

Fig. 7. - Ruínas da Armação da Pesca de Baleias de Bertioga, no extremo norte da Ilha de Santo Amaro, junto às da velha Igreja de Santo Antônio de Guaíbe, ou da Armação. 


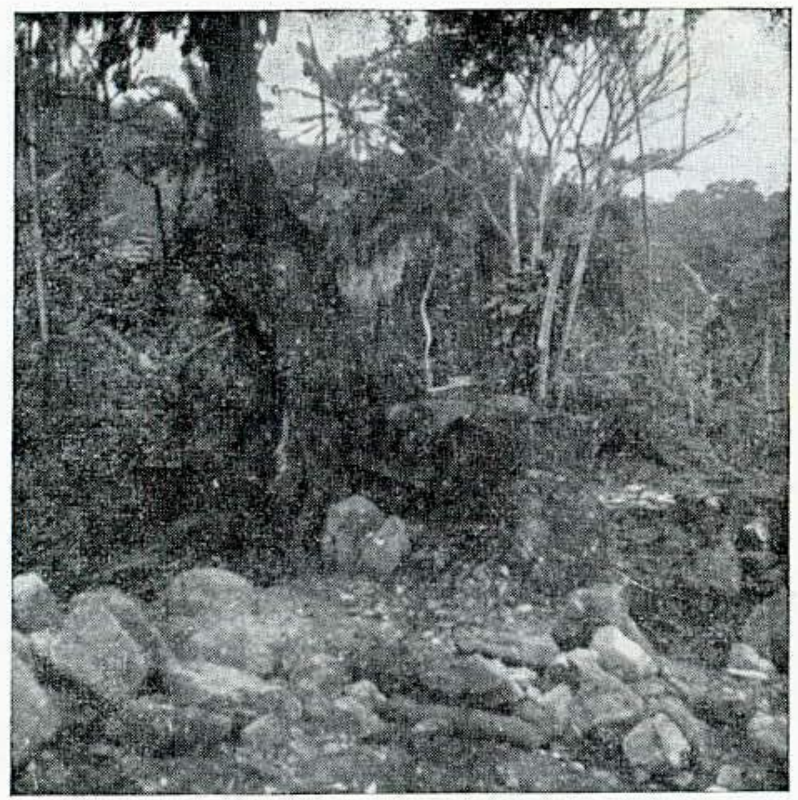

Fig. 8. - Restos da armação. No primeiro plano, uma árvore sustenta parte de um dos paredōes atualmente demolidos. No segundo plano, restos de uma antiga escada de acesso à Igreja de Santo Antônio de Guaíbe. (Fotografias do Exmo. Sr. Ademar Chaves, da "Sociedade Geográfica Brasileira" obtidas em 1956 e gentilmente cedidas pelo Autor).

*

* * *

\section{A P E N D I C E}

Assento que se faz com Domingos Gomes da Costa para estabelecer a sua custa uma nova armação nas Costas das Capitanias de São Paulo, e Santos, em que pediu por provisão se lhe registrasse e vai registrada no livro $5 .^{\circ}$ de ordens, fôlhas 78 .

Domingos Gomes da Costa por fazer serviço a Sua Magestade se oferece a estabelecer nas Costas das Capitanias de Santos e São Paulo do Estado do Brasil, uma nova fábrica e armação de pesca de Baleias, à sua custa, preparando-a e fabricando-a com todos aquêles preparos e apetrechos para ela conducentes, como são, barcas, canoas, casas, armazens, fornalhas, tanques, caldeiras de cobre, terras, escravos e tudo o mais de que ela carecer, sem outro algum interêsse mais do que o fazer-lhe Sua Magestade a graça de lhe dar livre a dita fábrica por tempo ide dez anos que hão de ter princípio do primeiro ano da pesca e ficando no fim dêles tôda a fábrica, suas pertences e doze escravos da dita armação, para a Fazenda Real, o que Sua Magestade houve por bem se aceitasse e ajustasse com o 
dito Domingos Gomes da Costa, por resolução de dezoito de agôsto dêste presente ano de mil setecentos e vinte e nove, tomada em consulta do Conselho Ultramarino de vinte e quatro de março do dito ano, com as condições abaixo expressadas, para cujo efeito será obrigado o dito Domingos Gomes da Costa a dar ao referido as fianças necessárias perante o Provedor da Fazenda Real da Capitania de São Paulo como ordenou o mesmo Conselho, por despacho do primeiro de setembro do dito ano.

Com condição que os azeites que não puderem ter saida nos distritos das Capitanias de Santos e São Paulo, os poderá êle Contratante, navegar para as Ilhas, Cidade de Lisboa, ou para onde quer que lhe pareça mais conveniente e como por falta de navegação para aquêles portos de navios, pretender ter efetivo um armazém no do Rio de Janeiro para dêste os poder transportar e navegar para os referidos portos ou quaisquer outros que lhe parecer por ser èste o pôrto de comércio mais vizinho; mas de tal sorte que não poderá êle Contratante vendê-los no dito pôrto da Cidade do Rio de Janeiro e só o poderá fazer em caso de urgente necessidade, sem que por esta o possa fazer por maior preço do que é costume venderem-se.

\section{II}

Com condição que não será obrigado a pagar dos ditos azeites e barbatanas das mesmas baleias durante o dito tempo de dez anos, porção alguma de direitos reais, subsídios nem tôdas contribuições nas ditas Capitanias de Santos, São Paulo e Rio de Janeiro, e menos de entrada neste pôrto, por não pretender vendê-los nele, e só sim navegá-los dai para fora.

\section{III}

Com condição que sendo-lhe necessárias terras nas costas das ditas Capitanias de Santos e São Paulo para melhor estabelecimento da dita fábrica, os Governadores delas lhas farão dar estando devolutas e não estando lhas farão vender pelo seu justo valor, o que tudo pertence sem o minimo detrimento das partes.

\section{IV}

Com condição que sendo-lhe necessária gente para trabalhar na dita pesca como em tôdas é corrente estilo em esta não quiser assistir, o poderá êle Contratante obrigar pelos Ministros daqueles distritos pagando-lhes o seu jornal que lícito e justo fôr por pender o bom sucesso da dita armação de homens peritos na dita pesca da baleia.

Com condição que os Governadores das ditas Capitanias de Santos e São Paulo e Rio de Janeiro lhes farão observar as condições referidas com todos os mais privilégios concedidos aos Contratantes ou arrematantes de contratos reais. 


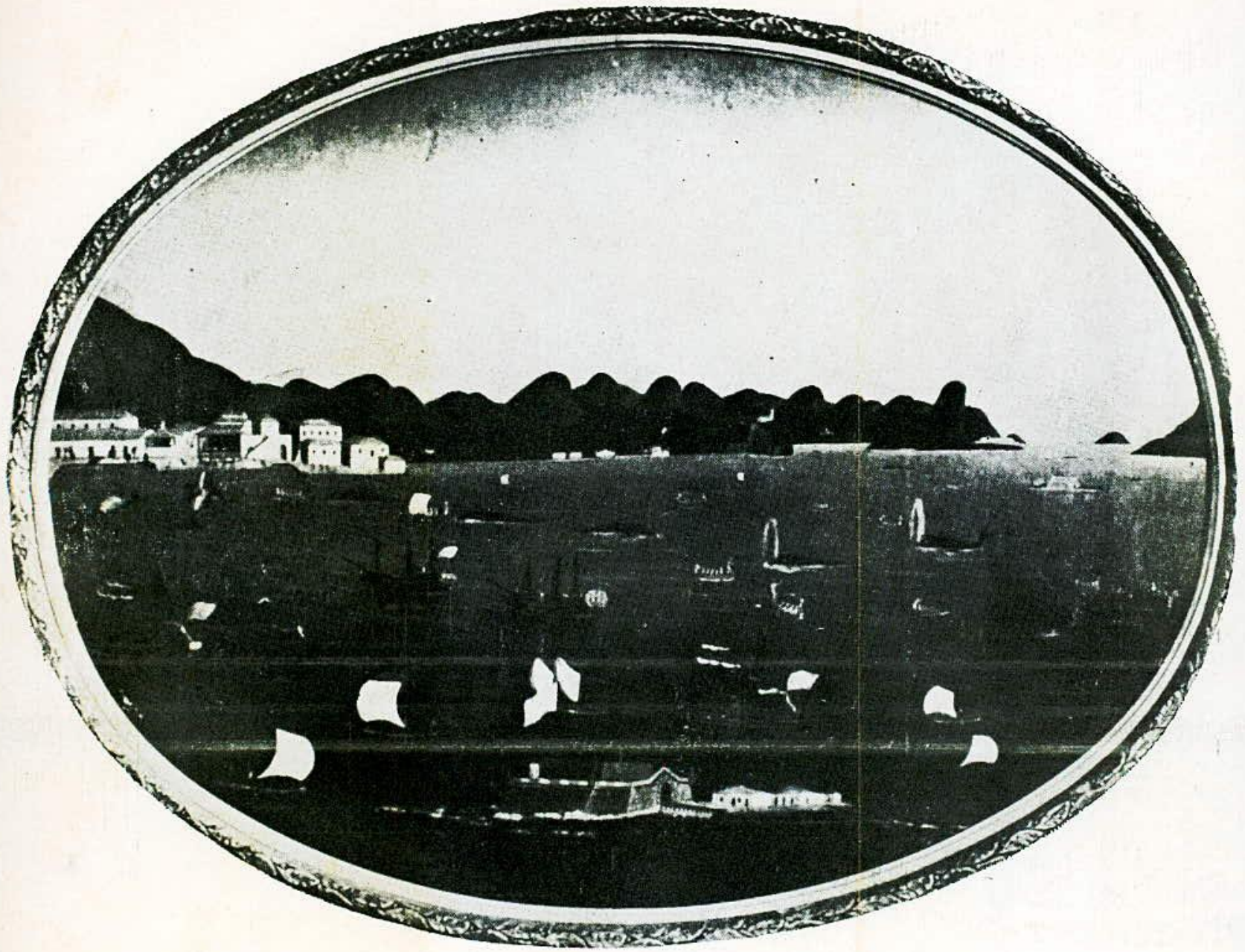

Fg. 9. - Pesca da baleia na baia de Guanabara. Cena maritima da sefunda metade do século XVIII

No primeiro plano: Villegaignon, o forte om a bandeira asteađa. Embarcacóes an coradas na baía. Baté's com as velas enfunadas circulando pelas proximidades.

No segundo plano: a baia. A Lage. B-leias. Lanchas baleeiras $\mathrm{em}$ pleno ataque aos mamíferos: arpoação e reboque cté os estaleiros da armação. Decepagem de dois cetáceos.

Ao fundo: rorros e enseadas, desde a Ponta da armaç o até a fortaleza de Santa Cruz. Ao longe, a Ilba Raza avistada pela entrada da barra. Dependenci-s de uma ar maçăo de pesca de baleias, possivelmente a de São Domingos que existiu no Distrito da Vila Real da Praia Grande, hoje Niterói.

O valioso e expressivo documento iconográfico é o quarto painel de uma série de seis de formato eliptico, que retratam aspectos do Rio de Janeiro colonial, conservados na sala D. João VI do Museu Histórico Nacional. São atribuidos ao artista fluminense, o mulato Leandro Joaquim, cuja autoria tem suscitado debates entre os estudiosos de iconografia brusileira do periodo colonial.

Leandro Joūquim, que ter'a falecido em 1798, foi amigo do Vice-rei, D. Luis de Vasconcelos e Souza e auxiliar do Mestre Valentim em desênho e construçóes. Pertenceu à Escola Fluminense de pintura. Dedicou-se à cenografia, à paisagem, ao retrato e à pintura sacra.

(A fotografia do painel aqui estämpada nos foi gentilmente enviada pelo dr. Américo Jacobina Lacombe, com valiosas informaçóes sỏbré o assunto.

Foram consultados os trabalhos de Gustavo Barroso, "Os Painé's de Leandro Joaquim", in "O Cruzeiro", n. ${ }^{\circ} 19$, de 26 de fevereiro de 1949, ano XXI e de Menezes de Oliva, "A Santa do Pau ôco e Outras Histórias", Rio de Janeiro, 1957, Gráfica Laemmert Limitada, que indica ampla bibliografia relativa aos quadros de Leandro Joaquim). 
E sendo visto pelos Senhores conselheiros do Conselho Ultramarino e Procurador da Fazenda dêle o conteúdo neste assento e suas condições, ordenou o mesmo Conselho que se lançasse neste livro dos contratos em que o dito Domingos Gomes da Costa se obrigou a cumprí-lo na forma que se declara no mesmo assento e condições dêle e pelos ditos senhores conselheiros foi aceito e dito que em nome de Sua Magestade se obrigavam a cumprílo na forma que nele se contém e para firmeza de tudo assinaram com o dito Domingos Gomes da Costa êste assento e dêle se lhe deu uma cópia assinada pelos senhores Antônio Rodrigues da Costa do Conselho de Sua Magestade e o Dr. José de Carvalho Abreu, conselheiros do Conselho Ultramarino. Antônio de Cobelos Pereira a'fêz em Lisboa ocidental a seis de setembro de mil setecentos e vinte e nove. Antônio Rodrigues da Costa. José Carvalho e Abreu. - Tirado do livro de contratos que serve na Secretaria do Conselho Ultramarino em que se acha lançàdo a fls. 411 verso. Lisboa ocidental, a 6 de setembro de 1729. André Lopes de Lavre.

\section{*}

Alvara que vinha nas costas escrito das condições atrás.

$\mathrm{Eu}$, El-Rei faço saber aos que êste meu alvará virem, que sendo-me presente o assento atrás escrito, que se fêz no meu Conselho Ultramarino, em virtude da minha resolução de dezoito de agôsto dêste presente ano, tomada em consulta do meu conselho com Domingos Gomes da Costa, em que se ofereceu a estabelecer nas costas das Capitanias de Santos e São Paulo, uma nova fábrica e armação 'de pesca de baleias à sua custa, preparando-a, e fabricando-a com todos aquêles preparos, e apetrechos para ela conducentes, como são barcos, canoas, casas, armazéns, fornalhas, tanques, caldeiras de cobre, terras, escravos e tudo o mais de que ela carecer sem outro algum interêsse mais do que o fazer-lhe eu a graça de lhe dar livre a dita fábrica por tempo de dez anos que hão de ter princípio do primeiro ano de pesca, ficando no fím dêles tôda a fábrica, suas pertences e idoze escravos da dita armação para a minha Fazenda como se declara no dito assento e condições dêle. Hei por bem de aprovar e ratificar o dito assento na pessoa do dito Domingos Gomes da Costa e mando se cumpra com tôdas as cláusulas e condições que nele se contém por êste meu alvará o qual valerá como carta e não passará pela chancelaria sem embargo da Ordenação do Livro $2 .^{\circ}$, tt.o 39 , etc., em contrário. Lisboa ocidental, seis de setembro ide mil setecentos, e vinte e nove - Rei. - O Secretário André Lopes de Lavre a fêzz escrever - Antônio de Cobelos Pereira o fêz.

(Arquivo Nacional. Rio de Janeiro: Coleção de Ordens Régias, n. $^{\circ}$ 64, Livro 3 , fls. 105 verso, a 106 verso. Manuscrito Inéclito).

*3

Que deixe dar cumprimento ao contrato das baleias de São Paulo.

D. João por graça de Deus, Rei de Portugal e dos Algarves, daquém é dalém mar em África senhor ide Guiné, etc., faço saber a vós Luis Vahia Monteiro, Governador da Capitania do Rio de Ja- 
neiro, que vendo-se o que me escrevestes em carta de vinte e oito de março do ano passado sôbre as condições com que Domingos Gomes da Costa se obrigou a fazer uma armação de pesca de baleias nas costas da Capitania de Santos e São Paulo, por cuja causa devia ser revogada a mercê que eu lhe fizera pelo prejuízo que resultava à minha Fazenda, me pareceu dizer-vos que dos prejuizos que considerais neste contrato, o mais forçoso é a diminuição que hão de ter as rendas reais do contrato dessa Capitania, a qual se acha ressalvada nas condições do dito contrato obrigando-se o Contratador a fazer boa tôda a diminuiçāo que tiver o dito contrato, e se vos avisa que o Contratador não pode vender azeite nessa cidade senão no caso de haver necessidade do dito gênero, e isto sem poder alterar o preço por que se vende e assim deveis dar inteiro cumprimento a êste contrato na forma das suas condições que vos apresentará o dito Contratador. EJ-Rei nosso senhor o mandou por Gon. çalo Manuel Galvão de Lacerda e o Dr. Alexandre Metelo de Souza Menezes, Conselheiros do seu Conselho Ultramarino; e se passou por duas vias. João Tavares a fêz em Lisboa ocidental a vinte e cinco de janeiro de mil sefecentos e trinta e um. O Secretário Manuel Caetano Lopes de Lavre a fêz escrever. - Gonçalo Manuel Galvão de Lacerda - Alexandre Metelo de Souza Menezes.

(Arquivo Nacional. Rio de Janeiro: Coleção de Ordens Régias, n. ${ }^{\circ}$ 64, Livro 3 , fls. 122 verso. Manuscrito Inédito).

Alvará da Rainha de Portugal permitindo a torlos os negociantes portuguêses o preparo e armação de navios para a pesca |da baleia $\dot{e}$ obtenção do azeite em alto mar e o estabelecimento de "Pescarias sedentárias" nas Ilhas de Cabo Verde.

"EU, A RAINHA Faço saber aos que êste Alvará virem: Que tendo-me sido presentes os graves inconvenientes, e a grande diminuição que causa na Marinha Mercante dos Meus Vassalos a restrição a que se tem julgado até aqui sujeitas as Pescarias Volantes das Baleias, colhidas no Alto Mar, e o Privilégio exclusivo do Contrato das Baleias para se não fazerem armações sedentárias em qualquer parte dos Meus Domínios: E sendo-me igualmente presente que para o Estabéecimento das Pescarias Volantes nada se acha concedido exclusivamente ao Contrato das Baleias; e que para as arniações se'dentárias em qualquer parte das Ilhas de Cabo Verde, os mesmos Contratadores generosamente cedem em favor da Minha Real Fazenda, de todo, e qualquer Direito que possão ter para impedir um semelhante, e tão útil Estabelecimento: Sou Servida determinar o seguinte.

Ordeno, que da publicação dêste Alvará em diante possão todos os Negociantes Portuguêses, cada um per si, ou reunidos em sociedade, preparar, e armar Navios destinados a pescar as Baleias, e preparar o seu Azeite no Alto Mar, em tôda e qualquer parte desde as Costas dêstes Reinos, até às do Brasil, e nas de Moçambique, prodendo depois vender o Azeite, e Barbas debaixo das mesmas Condições que os atuais Contratadores, ou seja nos Meus Dominios, ou exportá-los para fora do Reino. 
Ordeno igualmente que em qualquer das Ilhas de Cabo Verde fica livre a todo o Negociante Português poder fazer Pescarias sedentárias, e estabelecer Armazéns para o mesmo fim.

Que a todos os Pescadores de Baleia, de qualquer Nação que sejão, que vierem servir a bordo de Navios Portuguêses nas Pescarias Volantes, depois de assim o haverem praticado por tempo de dez anos sucessivos: Mando se lhes franqueem todos os Privilégios que são concedidos aos Meus Vassalos, ficando por êsse mesmo fato naturalizados Vassalos dos meus Reinos.

E estas mesmas Graças ficão concedidas a todos os Meus Vassalos em qualquer parte que habitem os Meus Dominios, seja no Reino, seja no Ultramar.

Pelo que: Mando a Mesa do Desembargo do Paço; Presidente do Meu Real Erário; Conselhos da Minha Real Fazenda, e do Ultramar; Real Junta do Comércio, Agricultura, Fábricas, e Navegacão dêstes Reinos, e seus Domínios; Vice-Rei e Capitão General te Mar e Terra do Estado do Brasil, e mais Governadores, e Capitães Generais das outras Capitanias do mesmo Estado, e das Ilhas; Governador das de Cabo Verde; e a todos os Magistrados, e mais Pessoas, a quem o conhecimento dêste Alvará pertencer, que o cumprão, e guardem e fação cumprir, e guardar tão inteiramente, como nele se contém, não obstantes quaisquer Leis, Regimentos, ou Orldens em contrário, que Hei por bem derogar para êste efeito sòmente, ficando aliás sempre em seu vigor: E ao Doutor José Alberto Leitão do Meu Conselho, Desembargador do Paço, e Chanceler Mor dêstes Reinos, Ordeno que o faça publicar na Chancelaria, registrando-se em todos os Lugares, onde se costumão registrar semelhantes IAlvarás, e guardando-se êste Original no Meu Real Arquivo da Tôrre do Tombo. Dado no Palácio de Queluz em 18 de maio de 1798.

$$
\begin{aligned}
& \text { P R f N C I P E } \\
& \text { D. Rodrigo de Souza Coutinho. }
\end{aligned}
$$

Alvará, por que Vossa Magestade há por bem permitir que todos os Negociantes Portuguêses possão preparar, e armar Navios, destinados a pescar as Baleias, e preparar o seu Azeite no Alto Mar, ficando-lhes livre poder fazer P'escarias sedentárias nas Ithas de Cabo Verde; tudo na forma acima declara.

Para Vossa Magestade ver.

Lourenço Antônio de Araújo o fêz.

Registrado nesta Secretaria de Estado dos Negócios da Marinha, e Dominios Ultramarinos em o Livro I de Cartas, Alvarás, e Patentes a fol. 130. vers. Nossa Senhora da Ajuda em 2 de junho de 1798.

$$
\text { Gervásio José Pacheco de Valadares. }
$$

José Alberto Leitão.

Foi publicado êste Alvará na Chancelaria Mor da Côrte e Reino. Liskoa 2 de junho de 1798.

\section{Jerônimo José Correa de Moura.}

Registado na Chancelaria Mor da Côrte e Reino no Livro das Leis a fol. 107 vers. Lisboa, 2 de junho de 1798 . 


\section{Manuel Antônio Pereira da Silva. \\ Na Régia Oficina Tipográfica".}

(Departamento do Arquivo do Estado de São Paulo. Biblioiea. - Lels de Portugal, reunidas e encadernadas, relativas aos anos de 1732 e 1799).

Alvará do Principe Regente D. João, de 24 de abril de 1801, abolindo o contrato do Estanque do Sal e o lda pescaria das baleias.

EU o PRINCIPE REGENTE Faço saber aos que este Alvará com força de Lei virem: Que Havendo consideração às grandes vantagens, que podem resultar à Minha Real Fazenda, e aos Povos, de se abolirem os Contratos da Pescaria das Baleas, e do Estanco do Sal do Brazil, ficando livre a todos o empregarem-se nestes dous interessantes ramos de Commercio Nacional; por quanto, pelo que respeita à Pescaria das Baleas, não sendo esta limitada como até agora a certas Costas do Brazil, mas extendendo-se a todas, e até ao alto mar, conforme o praticão as Nações mais industriosas da Europa, haverá necessariamente maior abundancia de Azeite de Peixe, e por consequencia huma diminuição sensivel no preço actual deste genero tão preciso para o Serviço lda Marinha, Fabricas, e Uso particular: E pelo que respeita ao Contrato do Sal, permittindo-se tambem a sua livre importação, e a sua Venda a todos os Portos da America, virá a resultar não só o beneficio da maior Extracção, e Consumo de hum genero, de que tanto abunda este Reino; mas conseguir-se-hão vantajosos progressos na maior Cultura, e Manufactura das ricas Producções da America, e hum attendivel augmento na Marinha Mercante. E Querendo ao mesmo tempo obviar os inconvenirentes, que se tem experimentado nas Capitanias do Pará, e Maranhão, nas quaes (não obstante não estar veldada a sua Importação e Venda) tem havido por vezes huma absoluta carencia deste genero, e grandes variações no seu preço, com irreparavel detrimento das Pescarias, e Salgas, por falta de providente Legislação, que sem restringir a liberdade do Commercio particular animasse, e promovesse o Interesse Público. E fazendo-se todos estes objectos dignos da Minha Real Contemplação, depois de ter ouviłdo sôbre elles a Real Junta do Commercio, e os Ministros do Meu Gabinete e Conselho, Tenho resolvido não só franquear o Commercio destes dous importantes Artigos, abolindo para êsse effeito os respectivos Contratos; mas conceder aos Meus Fieis Vassallos dos Dominios Ultramarinos a Faculdade de poderem tirar partido :da Cultura, e augmento das Salinas de Pernambuco, Cabo Frio, e Rio Grande, que pela Nona Condição do Contrato se achavão restrictas, e reduzidas a hum insignificante Producto. E sendo justo, por huma parte indemnizar de algum modo a Minha Real Fazenda da perda destes Rendimentos, que lhe ficão cessando; e por outra parte que os Povos não sejão perjudicados ou pela falta do Sal, por se verem obrigados a pagar esse genero por maiores preços, do que o pagavão no tempo do Contrato: Hei por bem, quanto à primeira parte, estabelecer em compensação alguns Impostos menos onerosos, e menos perjudiciaes ao adiantamento do Commercio, ao augmento da Cultura, e das Artes, que formão a Riqueza solida dos Estados; e quanto à segunda, formar huma Administração Regia, encarregada de fazer transportar todo o Sal, que couber nas Lotações dos Navios, para 
se vender nos Portos de seu destino pelos preços do Contrato findo, ou ainda por menos, se as circunstancias o permittirem; posto que a Minha Real Fazenda soffra algum prejuizo, por ser este menos sensivel, do que aquelle que póde resultar aos Povos, ou pela falta deste genero de indispensavel nećessidade, ou pelos maiores preços, que os Negociantes lhe pertendão impôr; ficando com tudo livre a estes o embarcarem todo o Sal de Sobrelotação, para o venderem no Brazil sem limitação de preço. E Querendo finalmente beneficiar por todos os meios possiveis aos Meus Fieis Vassallos dos Dominios Ultramarinos, promovendo o adiantamento da Agricultura, e facilitando os progressos da Mineração do Ouro, de que tirão a sua subsistencia, e ide que lhes resultão as maiores utilidades: Hei por bem conceder-lhes a Graça não só de isentar de Direitos todo o Ferro, que das Minas de Angola se exportar para os Portos do Brazil; mas Mandar crear hum Estabelecimento para a excavação das Minas de Sorocaba na Capitania de S. Paulo; e animar todos os Descubrimentos, que em outras quaesquer parte se possam fazer deste Metal; como tambem permittir se estabeleção Fabricas Reaes, para com o Salitre do Paiz se fabricar Polvora por conta de Minha Real Fazenda. Por tanto Sou Serviço Determinar o seguinte:

I. Ordeno e Declaro, que do dia primeiro de abril do corrente anno, em que acabarão estes dous Contratos, fica extincto o Privilegio Exclusivo, que a Minha Real Fazenda tinha determinado naquelles Generos; e que o seu Commercio seja livre a todos, e quaesquer dos Meus Vassallos em toda a parte dos Meus Dominios Ultramarinos; pagando os Direitos, que se achão estabelecidos, ou que Eu Hei por bem estabelecer pelo presente Alvará.

II. Ordeno e Mando aos Governadores do Brazli, que de commum acordo com as Juntas da Fazenda respectivas fação proceder logo aos Inventarios mais exactos, seja do Sal que se achar em ser no Termo do Contrato; seja dos Escravos, Fabricas, e Utencís pertencentes à Pescaria das Baleas; e tanto o respeito de um, como de outro objecto Quero se observem as Condições prescritas nos Contratos; e que prompta, e immediatamente se passe a realizar tudo, o que ficar pertencendo à Minha Real Fazenda, para tambem assim se satisfazer aos Contratadores, o que se lhes puder dever; verificando-se primeiro haverem elles da sua parte curnprillo as Condiçós da sua Arrematação: E como pela Segunda do Contrato do sal se determina, que os Contratadores que entrão de novo, recebão todo o Sal, que se achar existente no fim do Contrato; para se cumprir esta clausula, as Juntas da Fazenida das Capitanias, onde os Contratadores tiverem este Genero, o recebão para ser vendido por conta da Minha Real Fazenda, satisfazendo os mesmos Contratadores a sua importancia na fórma indicada nas suas Condiçōes.

III. Sendo Indispensável favorecer, e promover as Pescarias das Baleas no momento, em que as Declaro Livres: Ordeno aos Governadores, e Juntas da Fazenda que fação toda e possivel idiligencia, para conseguir a venda das Fabricas, e Escravos das armações. comprehendidas nos seus Districtos; e que não apparecendo Compradores, ponhão em Administração das Pescarias, ou procurem estabelecer algumas Sociedades de Negociantes, que encarregando-se da Escravatura, e mais objectos a ellas pertencentes, se incumbão de continuar, e ampliar as ditas Pescarias, sem com tudo se lhes con 
ceder Privilegio algum Exclusivo, pois o Hei por abolido; ficando obrigados ao pagamento dos Direitos, que se julgarem competentes, e a satisfazer à Minha Real Fazenda, o que da mesma receberem; por quanto Sou Servido facultar em beneficio commum, que não havendo compradores, que paguem as Fabricas com Dinheiro à vista, se possão estas vender, ou por junto, ou por partes com espera de pagamento: E em último lugar, que parecendo mais conveniente estabelecer alguma Sociedade interessada, o possão fazer, entrando a Minha Real Fazenda com o valor das Fábricas, como capital; e kde tudo o que os ditos Governadores, e Juntas da Fazenda praticarem a este respeito, Me darão Contas circunstanciadas tanto pela Secretaria de Estado do Ultramar, como pelo Erario Regio, e Conselho Ultramarino, a fim que Eu seja logo completamente informado da prompta execucão das Minhas Reaes Ordens; e continue a dar as ulteriores Providencias, que possão ainda ser necessarias.

IV. Para compensar a perda, que resulta à Minha Real Fazenda da abolição destes dous Contratos, Sou Servido estabelecer os seguintes Impostos, que principiarão a ter effeito desde o referido dia primeiro de Abril do Corrente anno de mil oitocentos e hum. Em primeiro lugar cada Moio de Sal pagará, quando dos Portos deste Reino se exportar para os do Brazil, os mesmos Quinhentos reis, que actualmente paga, quando se exporta para os Reinos Estrangeiros; e levará Guia das Alfandegas, para se lhe dar Entrada nos Portos do Brazil, sem pagar nelles mais cousa alguma; Todo o Sal, que se extrahir das Marinhas de Pernambuco, Cabo Frio, Rio Grande, ou de outras, que para o futuro se hajão de estabelecer, ou possão descubrir naquelle Continente, pagará Mil reis de Direitos por cada dez alqueires, medida das differentes Capitanias: Para a Cobrança destes Direitos ordenarão as Juntas da Fazenda respectivas a melhor formalidade, e méthodo, que for praticavel, para evitar os prejuizos, e descaminhos da Minha Real Fazenda: E pelo que pertence ao Imposto de Quatrocentos reis, que se cobrão por cada alqueire de sal na Vila de Santos, Hei por bem, que fique subsistindo, e se arrecada pela fórma que se acha estabelecido. Em segundo lugar ordeno que a todo o Brazil se extenda a obrigação de servir-se de Papel Sellado, da mesma forma que se acha estabelecido, ou possa estabelecer-se no Reino, e variando sómente no modo de Arrecadação, que será conforme o que Determino em algumas Disposições deste Alvará. Em terceiro lugar Declaro genero privativo, e estancado para a Real Fazenda, o Salitre, e Polvora, da fórma que vai abaixo declarado: Estes tres Impostos, que Mando crear de novo, ficarão applicados para parte dos mesmos fins, a que erão destinados os Rendimentos dos dous Contratos abolidos.

V. Ordeno que a Arrecadação do novo Imposto do Sal, que se exporta para o Brazil, fique confiada à mesma Repartição, que actualmente cobra os Direitos existentes do mesmo Genero; a qual fará subir annualmente à Minha Real Presença huma Relação do Sal exportado para aquelles Dominios, a fim de se combinar com a que Determino Me seja remettida de cada huma das Capitanias das porções de Sal, que tambem em cada anno se tiverem importado para o seu Consumo: E para que não falte na America Hum Genero tão preciso, Ordeno que os Navios, que sahirem de Lisboa para qualquer dos Portos do Brazil não sejão admittidos a despacho sem le- 
varem a mesma Lotação de Sal, que exportavão os Contratadores, e que deverá agora exportar-se por conta da Administração Regia, que para este effeito Sou Servido crear, composta do Thesoureiro Mór do Meu Real Erario, do Intendente da Marinha, de hum dos Contadores Geraes do mesmo Erario, e de hum Negociante desta Praça, que nomear o Meu Ministro, e Secretário de Estado dos Negocios da Fazenda, Presidente do Meu Real Erario; ficando com tudo livre a cáda Navio o poder levar mais Sal, além da Lotação ordinária, por conta de Particulares; porque só em caso de urgencia poderá a Administração mandar Sal de Sobrelotação, prevenindo para isso antecipadamente os donos dos Navios. Pelo que pertence ao Commercio do Sal para os Portos das Capitanías do Pará, e Maranhão, e outros onde até agora era livre, continuará a gozar da mesma liberdade: e todo o Negociante poderá navegar para os mesmos Portos o Sal, que quizer, e vender pelos preços, que julgar convenientes, pagando os direitos estabelecidos.

VI. A Junta da Administração, que pelo presente Alvará Sou Servido crear, e de que Confio a boa Arrecadação deste Negocio, poderá eleger as pessoas, que forem necessarias para o seu costeio neste Reino; e estabelecer correspondencias nos diferentes Portos do Brazil; regulando-se este respeito pelas Instrucções, que Tenho Mandado formalizar para o Regimen da Administração: E Ordeno que o Thesoureiro Mór do Meu Real Erario entregue à mesma Administração as Sommas, que por Portarias do Presidente do mesmo Real Erário lhe forem determinadas para satisfação das compras de Sal, e mais despezas, de que he encarregada; tendo para este effeito a dita Administração no Erario o seu Cofre separado: E sendo da Minha Real Intenção que os Povos não experimentem faltas, e que desta Administração lhes resulte o maior beneficio: Determino que a distribuição, e venda do Sal seja encarregada às Camaras dos differentes Destrictos das Capitanias; e que as Juntas das Fazendas fação entrar, e arrecadar nos Cofres das suas respectivas Thesourarias o producto das mesmas vendas em certos, em determinaidos tempos; e que fiscalizem, e vigiem sobre as mesmas Camaras a fim de executarem devidamente esta Incumbencia, e não Excederem na venda do Sal os preços estabelecidos; devendo dar conta immediatamente de todo, e qualquer abuso, que seja prejudicial à Minha Real Fazenda, ou ao Servíço público, e Utilidade dos Povos.

VII. A Addministração receberá todo o Sal, que se achar embarcado pelos Contratadores passados, pelo seu valor actual, conforme se tem convencionado; cuja importância será paga em Apolices, segundo elles quizerem; e o mandará vender no Brazil, como Effeitos proprios da Minha Real Fazenda.

VIII. O frete do Sal da Lotação dos Navios, que se destinarem aos: Portos do Pará, e Maranhão, será de dous mil reis por Moio; e havendo urgencia de que por conta ta Administração se mande Sal além da Lotação, se fixará o preço do dobro do Frete por cada Moio, que exceder à dita Lotação: Para os Portos porém, que erão sujeitos ao Contrato, se ficará praticando pela Administração, o que se acha actualmente estabelecido. 
IX. O Meu Ministro da Fazenda poderá arbitrar ordenados, ou gratificações annuaes aos Deputados da Junta da Administração pelo trabalho desta Incumbencia; para o que o Authorizo, como tambem para approvar todas as Providencias, e Disposições economicas, que a mesma Administração julgar convenientes tanto a respeito da exportação do Sal deste Reino, como do emprego do Producto na sua venda na America; regulando o termo fixo, em que as Correspondencias deverão prestar contas, e fazer as remessas do Dinheiro, ou Effeitos, conforme lhes for determinado; e da mesma Approvação ficarão dependentes todas as despezas, que se houverem de fazer para o costeio desta Negociação.

X. Para evitar as faltas de Sal nas Capitanías, e as variações que se experimentão nos preços do mesmo genero, ч Junta da Administração mandará logo proceder à Medida, e Arqueação de todos os Navios Mercantes, que navegão para o Pará, e Maranhão, e outros Portos não sujeitos ao Contrato finłlo; e que fi se a cada hum delles a Lotação de Sal, que deve levar, seguindo os mesmos principios anteriormente praticados com os Navios, que navegão para os Portos sujeitos ao Contrato. E Declaro, que todos os Navios destinados para os referidos Portos não poderão desde a Publicação deste Alvará obter os passaportes, e despachos do estilo, sem que primeiro mostrem levar a Lotação, que lhe for arbitrada por conta da Administração, de que lhe passará a conveniente Declaração: $\mathrm{Pa}$ ra os Portos porém do Contrato ficará em seu vigor, a respeito das Arqueações, e preços dos fretes do Sal de Lotação, o mesmo, que até agora se tem praticado.

XI. Para não vexar os donos dos Navios, obrigando-os a levar Sal por sua conta e risco: Ordeno que a Junta da Administração mande com muita antecedencia apromptar o Sal, que for necessario para a Lotação dos Navios, que houverem de partir; em maneira tal, que seus donos não experimentem já mais falta alguma; e poderá a mesma Junta (parecendo-lhe conveniente) mandar fazer na Cidade do Porto o provimento necessario de Sal para a Lotação dos Navios, que daquelle Porto sahirem para os do Brazil; fazendo-o transportar para este effeito de Setubal, Figueira, ou ainda desta Cidade.

XII. A Junta da Administração remeterá o Sal às Correspondencias, que nomear nos Portos do Pará, e Maranhão, onde (sendo necessário) se estabelecerão Armazens Públicos, em que este Genero se receba, para dalli se distribuir, e ser vendido ao Povo por hum preço, que não exceda o de setecentos reis por Alqueire, que Estabeleço agora para as ditas Capitanias, ordenando também que todos os Habitantes das mesmas Capitanias, que necessitarem de Sal para grandes Pescarias, e Salgas de Carnes; e que no fim do anno mostrarem ter consumido nestes tão interessantes objectos mais de quinhentos moios de Sal, se lhes venda este a preço de seiscentos reis, ou ainda por menos sendo possivel; havendo cuidado que esta Graça se não extenda por abuso aos que tal emprego não fizerem: Para os Portos porém, que erão sujeitos ao Contrato, se não exederão os preços ja estabelecidos; e se concederá sempre algum favor aos que tiverem feito Estabelecimentos de grandes Pescarias. 
(Seguem-se 4 páginas sôbre o uso do Papel Sellado e dispondo sôbre vendas de Salitre, e Polvora, e Estabelecenłlo Fabricas dêsse gênero, e regulando a exportação de Ferro de Angola para o Brasil).

Pelo que: Mando à Meza do Desembargo do Paço; Presidente do Real Erario; Regedor da Casa da Supplicação; Conselhos da Minha Real Junta de Ultramar; Conselho do Almirantado, e Real Junta da Fazenda da Marinha; Real Junta do Comercio, Agricultura, Fabricas, e Navegação destes Reinos, e seus Dominios; Vice-Rei, e Capitão General de Mar e Terra do Estado do Brazil, e mais Governadores, e Capitães Generaes, das outras Capitanias do mesmo Estado; e a todos os Tribunaes, Magistrados, e Pessoas, a quem o Conhecimento deste Alvará pertencer, que o cumprão, guardem e fação inviolavelmente cumprir, e guardar tão inteiramente, como nelle se contém, não obstante quaesquer Leis, Regimentos, ou Ordens em contrario, qeu Hei por bem derogar para este effeito sómente, ficando aliás sempre em seu vigor: E ao Doutor José Alberto Leitão, do Meu Conselho, Desembargaddor do Paço, e Chanceller Mór destes Reinos, Ordeno que o faça publicar na Chancellaria, registrando-se todos os Lugares, onde se costumão registar semelhantes Alvarás, e lançandose este Original no Meu Real Archivo da Torre do Tombo. Dado no Palacio de Quéluz em vinte e quatro de Abril de mil oitocentos e hum.

\section{P R I N C I P E}

\section{Dom Rodrigo de Sousa Coutinho.}

Alvará com força de Lei, pelo qual Vossa Alteza Real, em commum beneficio de Seus Vassalos existentes nos Dominios do Brazil, e franqueza do Commercio, He Servido abolir os idous Contratos da Pescaria das Balèas, e do Estanco do Sal nos Braziz; ampliando o Commercio dos referidos generos: compensando com Impostos novos o perjuizo de Sua Real Fazenda na Abolicão dos referidos Contratos: Creando huma Administração Regia para mesma Lotação de Sal, que destes Reinos exportavão os Extinctos Contratadores; Constituindo Privativas da Real Fazenda as Vendas do Salitre; e Polvora, e Estabelecendo Fabricas deste Genero; Concedendo livre de Direitos por dez annos a Extracção, e Exportação do Ferro do Reino de Angola para o Brazil; E dando finalmente as justas Providencias sobre o Ferro, que se extrahir das Minas da Capitania de S. Paulo, ou das que ainda se descubrirem na de Villa Rica para o consumo das outras Capitanias. Tudo na fórma assima declarada.

\section{Para Vossa Alteza Real ver.}

Registado nesta Secretaria de Estado dos Negocios da Fazenda a fol. 5 do Liv. I de Cartas, e Alvarás. Lisboa 15 de Maio de 1801.

José Anastacio da Costa e Sá.

José Alberto Leitão .

Foi publicado este Alvará com força de Lei na Chancellaria Mór kla Corte, e Reino. Lisboa, 16 de Maio de 1801. 
Jeronymo José Correa de Moura.

Registado na Chancellaria Mór da Corte, e Reino do Livro das Leis a fol. 157 vers. Lisboa, 16 de Maio de 1801 .

Manoel Antonio Pereira da Silva.

José Anastacio da Costa e Sá o fez.

Na Regia Officina Typografica.

(Documento impresso na Régia Oficina Tipográfica e também publicado na Colecção de Legislação Portugueza desde a ultima compilação das Ordenações, redigida pelo Desembargaidor Antonio Delgado da Silva, volume de 1791 a 1801 , Lisboa, 1828. Typ. Maigrense, p. 694).

$$
* *
$$

\section{F O N T E S}

\section{DOCUMENTOS IMPRESSOS.}

1). - “Alvará de D. Maria I, dado no Palácio de Queluz a 18 de maio de 1798, sôbre poderem os Negociantes Portuguêses armar navios destinados à pesca das baleias e ao preparo do azeite em alto mar em tôdas as costas do Reino, do Brasil e de Moçambique, podendo vender e exportar o azeite e as barbatanas..." - Departamento do Arquivo do Estado de São Paulo - Biblioteca - Coleção de Leis encadernadas de Portugal, vol. de 1732 a 1799 .

2). - "Assento que se fez com Thomé Gomes Moreira por seu bastante Procurador Luiz Antonio Correa da Silva, para estabelecer à sua conta huma nova armação, e fabrica de pesca de Baleas na Ilha de Santa Catharina..." - Departamento do Arquivo do Estado de Sáo Paulo - Biblioteca -. Coleção de Leis encadernadas de Portugal, vol. de 1732 a 1799 .

3). - “Cartas Régias", 1651-1667. - Documentos Históricos, vol. LXVII. Ministério da Educação e Saúde. Biblioteca Nacional. Typ. Baptista de Souza. Rio de Janeiro, 1944.

4). - “Cartas Régias", 1667-1681. - Documentos Históricos, vol. LXVII. Ministério da Educação e Saúde. Biblioteca Nacional. Rio de Janeiro, 1945. Typ. Baptista de Souza.

5). - "Cartas Régias", 1681-1690: "Portarias", 1719-1720. - Documentos Históricos, vol. LXVIII. Ministério da Elducação e Saúlde. Biblioteca Nacional. Rio de Janeiro, 1945. Typ. Baptista de Souza.

6). - "Collecçâo da Legislação Portugueza, desde a ultima compilação das Ordenaçôes Redegida pelo Desembargador Antonio Delgado da Silva". Legislação de 1750 a 1762. Lisboa, 1830. Typ. Maigrense. 
7). - "Collecção' de Legislacẫo Portugueza, desde a ultima compilaçâo das Ordenaçôes - Redegída pelo Desembargador Antonio Delgado da Silva". Legislação de 1791 a 1801. Lisbia, 1828. Typ. Maigrense.

8). - "Condiçoens do Contrato da Pescaria das Baleyas nas Costas do Brazil, e Ilhas a ellas adjacentes arrematado na Secretaria de Estado dos Negocios da Marinha e Dominios Ultramarinos. A Ignacio Pedro Quintella e Companhia...". Lisboa. Na Offic. de Miguel Rodrigues, Impressor do Eminentissimo Senhor Cardial Patriarca. Anno M.DCG.LXV." - Departamento do Arquivo do Estado de São Paulo Livro 169. Tempo Colonial: "Avisos e Cartas Regias - 1765 a 1767".

9). - "Contratos da Pesca das Baleas do Rio de Janeiro, Ilhas de S. Catharina, e S. Sebastião, Santos e S. Paulo, que se fizerão no Conselho Ultramarino com Francisco Peres de Sousa por tempo de seis annos, em preço cada hum delles de quarenta e oito mil cruzados, e cem mil reis". Lisboa. $\mathrm{Na}$ Officina de Miguel Manescal da Costa, Impressor bo Santo Officio. Anno 1755. - Departamento do Arquivo do Estado de São Paulo - Biblioteca - Coleção de Leis encadernadas de Portugal, vol. de 1732 a 1799 .

10). - "Inventário de Documentos Relativos ao Brasil existentes no Arquivo da Marinha e Ultramar de Lisboa, organizado por Eduardo de Castro e Almeida". Annaes da Biblioteca Nacional do Rio de Janeiro, vol. XXXIX, Rio de Janeiro, 1616-1729, VI. Rio de Janeiro. Off. Graph. Bibl. Nac., 1921. Vol. XLVI, Rio de Janeiro, 1747, VII. Rio de Janeiro, Off. Graph. Bibl. Nac., 1934.

11). - "Patentes, Provisões e Alvarảs". 1637-1639. - Documentos Históricos, vol. XVII, da série XV dos Documentos da Biblioteca Nacional. Biblioteca Nacional. Rio de Janeiro, 1930. Typ. Monroe.

12). - "Provedoria da Fazenda Real de Santos. Leis, Provisões, Alvarás. Cartas e Ordens Reaes". Documentos Históricos, vol. I. Archivo Nacional. Rio de Janeiro, 1928. Braggio \& Reis.

13). - "Provisões, Alvarás e Sesmarias". 1639-1655 _ - Documentos Históricos, vol. XVIII da série XVI dos Documentos da Biblioteca Nacional. Biblioteca Nacional. Rio de Janeiro, 1930. Typ. Monroe.

14). - “Provisões - Patentes - Alvarás". 1695-1697. - Documentos Históricos, vol. LVII. Ministério da Educação e Saúde. Biblioteca Nacional. Typ. Baptista de Souza. Rio de Janeiro, 1942 .

15). - "Provisões - Patentes - Alvarás". 1697-1699. _ Documentos Históricos, vol. LVIII. Ministério da Educação e Saúde. Biblioteca Nacional. Typ. Baptista de Souza. Rio de Janeiro, 1942 . 
16). - “Provisões, Patentes, Alvarás, Mandados". 1651-1693. - Documentos Históricos, vol. XXXIII. Biblioteca Nacional. Typ. Arch. de Hist. Brasileira. Rio de Janeiro, 1936.

17). - "Provisões, Patentes, Alvarás, Sesmarias, Mandados, etc.", 1678-1681. Documentos Históricos, vol. XXVII. Biblioteca Nacional. Rio de Janeiro, 1934. Typ. Arch. de Hist. Brasileira.

18). - "Registo de Cartas Régias". 1678-1684. Documentos Históricos, vol. LXXXII. Ministério da Educação e Saúde. Biblioteca Nacional. Rio de Janeiro, 1948.

19). - "Registo de Cartas Régias". 1683-1697. Documentos Históricos, vol. LXXXIII. Ministério da Educação e Saúde. Biblioteca Nacional. Rio de Janeiro, 1949.

20). - "Registo de Cartas Régias". 1697-1705. Documentos Históricos, vol. LXXXIV. Ministério da Educação e Saúlde. Biblioteca Nacional. Divisão de Obras Raras e Publicações. Rio de Janeiro, 1949.

21) . - "Registo do Conselho da Fazenda". Bahia - 1699-1700. Documentos Históricos, vol. LXV. Ministério da Educação e Saúde. Biblioteca Nacional. Rio de Janeiro, 1944. Typ. Baptista de Souza.

\section{DOCUMENTOS MANUSCRITOS.}

I) . - Arquivo Histórico Ultramarino de Lisboa.

1). - "Contracto das Baleias do Rio de Janeiro que se fes no Conselho Ultramarino com Manuel Gomes de Brito como procurador bastante de Domingos Pinto de Magalhães por tempo de tres anos e preço em cada hũ deles de vinte e dois mil cruzados livres para a fazenda Real. Lisboa Ocidental, 5 de Maio de 1728". Cód. 296.

2). - "Contrato da pesca das baleias que se fes no Conselho Ultramarino com Simão Lobo Guimarães por tempo de seis anos e preço em cada um deles, de trinta e sinco mil e quinhentos cruzados livres para a Fazenda Real. Lisboa Ocidental, 11 de Janeiro de 1729". Cód. 296.

3). - "Contrato das baleias do Rio de Janeiro que se fes no Conselho Ultramarino, com Manuel Gomes de Brito como procurador bastante de José Vieira Souto por tempo de tres anos que hão de principiar em o primeiro ide Abril de 1732 em preço cada um deles de vinte mil e quinhentos cruzados livres para a Fazenda Real. Lisboa Ocidental, 1 de Março de 1731". Cód. 296.

4). - "Documentos Avulsos do Rio de Janeiro". Caixa de 1802.

5). - “Documentos do Rio de Janeiro" - Caixa de 1749-1750.

6). - "Documentos do Rio de Janeiro" - Caixa de 1718-1722.

7). - "Papéis do Rio de Janeiro" - Maço 33 D. C. 
II). - Arquivo Nacional. Rio de Janeiro.

8). - "Assento que se faz com Domingos Gomes da Costa para estabelecer á sua custa uma nova Armação nas Costas das Capitanias de São Paulo e Santos em que pediu por provisão se lhe registrasse...". Coleção de Ordens Régias, n. 64, Livro 3.

9). - "Cartas Régias. Provisões, Alvarás e Avisos". 16621821. Em avulso, vol. 37; Cartas Régias, vol. 161; Em avulso, vol. 16; Vol. 26. Coleçẫo de Ordens Régias, $n$. 64, Livro 3.

10). - "Correspondência dos Governadores do Rio de Janeiro com diversas autoridades". Coleçẫo 84, Livro III.

11). - "Correspondência dos Governadores do Rio de Janeiro com diversas autoridades". Coleçấo 84. Livro XIII.

III). - Biblioteca Nacional. Rio de Janeiro.

12). - "Carta do Gonde dos Arcos, datáda do Rio de Janeiro a 28 de Fevereiro de 1807, ao Capitão Tenente Pedro Antonio Nunes, sôbre as providências a serem tomadas contra os navios estrangeiros que praticavam a pesca volante das baleias no litoral de Santa Catarina até o Rio da Prata", com vários "Anexos", sôbre o mesmo assunto.

13). - "Projeto do Alvará abolindo o Contrato da pescaria de baleias e do estanque do sal no Brasil e estabelecendo outros impostos que vigorarão a partir de 1 de Abril de 1801.

IV). - Departamento do Arquivo do Estado de São Paulo.

14). - "Avisos e Cartas Régias", 1765-1767. Livro Manuscrito, 169. Tempo Colonial.

15). - “Avisos e Cartas Régias", 1778-1796. Livro Manuscrito, 171. Tempo Colonial.

16). - "Avisos e Cartas Régias", 1796-1802. Livro Manuscrito 173. Tempo Colonial.

17). - "Patentes e Cartas Régias", 1745-1765. Livro Manuscrito 51. Tempo Colonial.

18) . - "Maço de População de Santos". 1765-1799. Tempo Colonial.

19) . - "Maço de População de São Sebastião". 1765-1797. Tempo Colonial.

20). - "Provisões Régias". 1746-1763. Livro Manuscrito 189. Tempo Colonial.

21). - "Registro das Condições e assento com o alvará com que foi arrematado a Tomé Gomes Moreira o Contrato da Armação das Baleias ida Capitania do Rio de Jaŕeiro, 
Santos e São Paulo...". Com mais documentos anexos. Livro Manuscrito 51. Tempo Colonial, "Patentes e Cartas Régias". 1745-1765.

V). - Instituto Histórico e Geográfico Brasileiro.

22). - Conselho Ultramarino. "Vúrios", tomo 5.

CRONISTAS, INFORMANTES E VIAJANTES.

1). - ANCHIETA, José de - "Informação da Provincia do Brasil para Nosso Padre. 1585". In "Cartas, Informações, Fragmentos Historicos e Sermões do Padre..." (1554-1594). Publicação da Academia Brasileira. Rio de Janeiro, 1933. Civilização Brasileira, A. S. - Atribuida ao Pe. José de Anchieta, na verdade foi escrita pelo Pe. Fernão Cardim, segundo o Pe. Serafim Leite, que a encontrou no Arquivo da Companhia de Jesus, em Roma. (Códice Brasília 15, 333339 , ou seja a "Informação da provincia do Brasil para nosso Padre", datada da Bahia a 31 de dezembro de 1583) José Honório Ródrigues - "Historiografia del Brasil, siglo XVI, México, 1957. Instituto Panamericano de Geografia e História.

2). - ANONIMO - "De Algumas cousas mais notaveis do Brasil". (Informação jesuítica de fins do Século XVI). Revista do Instituto Histórico é Geográfico Brasileiro, tomo 94, vol. 148. 1923. Rio de Janeiro, 1927. Imprensa Nacional.

3). - ARAUJO, José de Souza Azevedo Pizarro e - Memorias Historicas do Rio de Janeiro". 9 volumes. Ministério da Educação e Saúde. Instituto Nacional do Livro. Imprensa Nacional. Rio de Janeiro, 1945-1948.

4). - BRITO, Paulo Jozé Miguel de - "Memoria Politica sobre a Capitania de Santa Catarina. Escrita no Rio de Janeiro em o anno de 1816 por...". Lisboa. Typ. da Academia Real das Sciencias. 1829.

5). - CALDAS, José Antonio - "Noticia Geral dè Toda esta Capitania da Bahia desde o seu descobrimento até o Presente ano de 1759". Ed. Fac-Similar. Tipografia Beneditina Ltda. Salvador, 1951.

6) . - CARDIM, Fernäo - "Tratados da Terra e Gente do Brasil". Introdução e notas de Baptista Caetano, Capistrano de Abreu e Rodolfo Garcia. 2a. ed. Companhia Editôra Nacional. São Paulo, 1939. Série Brasiliana.

7). - CASAL, Aires de - "Corografia Brasilica", tomo II. FacSímile da ed. de 1817. Ministério da Éducação e Saúde. Instituto Nacional do Livro. Imprensa Nacional. Rio de Janeiro, 1947.

8). - DAMPIER, Guillaume - "Voyage aux terres Australes, à la nouvelle Hollande \&C. fait en 1699. Où l'on trouve la Description des Isles Canaries, des Isles de Mayo \& de S. Iago, de la Baye de Tous des Saints, des Forts \& de la Ville de Bahia dans le Brésil, \&C. Par...". Tome IV. A' Rouen. Chez Eustache Herault. (Cour du Palais). M.DCC.XV.

9). - DENIS, Ferdinand - "Brésil". Paris, MDCCCXXXVII. Firmin Didot Frères Editeurs. 
10). - FREYRE, Francisco de Brito - "Viagem da Armada da Companhia do Commercio, e Frotas do Estado do Brasil. A Cargo do General Francisco de Brito Freyre". Impressa por mandado de El Rey Nosso Senhor. Anno 1655 .

11). - GANDAVO, Pero de Magalhães - "Historia da Provincia ide Santa Cruz". Edição da Typ. do Annuario do Brasil. Rio de Janeiro, 1924 .

12) . - KIDDER, D. P. e FLETCHER, J. C. - "O Brasil e os Brasileiros" (Esbôco Histórico e Descritivo). 2." vol. Trad. de Elias Dolianiti. Cia. Editôra Nacional. São Paulo, 1941. Série Brasiliana.

13) . - KNIVET, Antonie - "The admirable adventures and strange fortunes of Master..., which went with Master Thomas Candish in his second voyage to the South Sea. 1591. In Samuel Purchas. B. D. Hakluytus Posthumus or Purchas His Pilgrimes, XVI. Glasgow, 1906.

14). - LERY, Jean de — "Viagem à Terra do Brasil". Trad. e notas de Sérgio Milliet. São Paulo, 1941. Livraria Martins. Biblioteca Histórica Paulista, vol. VII. Emp. Gráf. Revista dos Tribunais.

15) . - MARTIUS, C. F. P. e SPIX, J. B. von - "Viagem pelo Brasil". Tradução de Lucia Furquim Lahmeyer. Rev, por B. F. Ramiz Galvão e B. de Magalhães que foi também o anotador. $2 .^{\circ}$ vol. R. de Janeiro, 1938. Imprensa Nacional.

16). - MAWE, John - "Viagens ao Interior do Brasil, principalmente aos distritos de ouro e dos diamantes". Tradução de Solena Benevides Viana. Introd, e notas de Clado Ribeiro de Lessa. Rio de Janeiro, 1944. Ed. Zélio Valverde.

17) . - PITTA, Sebastião da Rocha - "História da America Portugueza des'de o ano de mil e quinhentos do seu descobrimento até o de mil e setecentos e vinte e quatro". 2a. edição, revista e anotada por J. G. Goes. Lisboa, M.DCCCLXXX. Ed. Francisco Arthur da Silva.

18) . - PYRARD, de Laval, François - "Extracto das Viagens de... relativo à estada deste navegante no Brazil em 1610". Tradução de Affonso d'Escragnolle Taunay. Revista do Institituto Histórico e Geográfico de São Paulo, vol. XIII. 1908. São Paulo, 1911. Typ. do Diário Oficial.

19) . - SAINT-HILAIRE, Auguste — "Viagem à Provincia de Santa Catharina (1820)". Tradução de Carlos da Costa Pereira. São Paulo, 1936. Companhia Editôra Nacional. Série Brasiliana.

20) . - SALVADOR, Frei Vicente do - "História do Brasil. 15001627". Terceira edição revista por Capistrano de Abreu e Rodolpho Garcia. Companhia de Melhoramentos de São Paulo. São Paulo, s.-d.

21). - SEIDLER, Carl - "Dez anos no Brasil". Tradução e notas do General Bertoldo Klinger. São Paulo. Livraria Martins. s-d. Biblioteca Histórica Brasileira, vol. VIII.

22) . - SOUSA, Gabriel Soares de - "Tratado Descriptivo do Brasil em 1587". Comentários de Francisco Adolpho Varnhagen. Terceira edição. Companhia Editôra Nacional. São Paulo, 1938. Série Brasiliana. 
23) . - VASCONCELLOS, Simão de - "Noticias curiosas e necessarias das cousas do Brasil. Pello Padre... da Companhia de Iesus". Em Lisboa. Na Officina de Ioam da Costa. Anno 1668 .

24) . - VILHENA, Luiz dos Santos - "Recopilação de Noticias Soteropolitanas e Brasilicas". 2 volumes. Bahia, 1921. Imprensa Official do Estado.

\section{OBRAS GERAIS E ESPECIALIZADAS.}

(1) . - AZEVEDO, J. Lúcio de - "Novas Epanáforas". Livraria Clássica Editôra. Lisboa, 1932.

2) . - AZEVEDO, J. Lúcio de - "Épocas de Portugal Econômico — Esboços de História". 2a. edição. Livraria Clássica Editôra. Lisboa, 1947.

3) . - AZEvedo, J. Lúcio de - "O Marquês de Pombal e a sua época”. Segunda edição. Editôres: Annuario do Brasil. Rio de Janeiro. Seara Nova. Lisboa. Renascença Portuguesa. Pôrto (Typographia Annuario do Brasil). (Almanack Laemmert). Rio de Janeiro, 1922.

4) . - BALBI, Adrien - "Essai Satistique sur le Royaume de Portugal et d'Algarve Comparé aux autres états de l'Europe". Tome premier. Paris, chez Rey et Gravier Libraires, 1822.

5) . - BEIRÃO, Caetano - "D. Maria I (1777-1792)". Terceira edisão. Lisboa, 1944. Emprêsa Nacional de Publicidade.

6). - BESNARD, Wladimir - "Les produits d'Origine Marine et Fluviale". Paris, 1948. Payot.

7). - CAMARA, Antonio Alves - "Ensaio sobre as Construcções Navaes Indigenas do Brasil". Rio de Janeiro, 1888. Typ. de G. Leuzinger \& Filhos .

8). - CAMARA, Antonio Alves - "Pescas e Peixes da Bahia". Rio de Janeiro, 1911. Typ. Leuzinger.

9). - CARNAXIDE, Antonio de Sousa Pedroso de (Visconde de Carnaxide) - "O Brasil na Administração Pombalina (Economia e Politica Externa)". Companhia Editôra Nacional. São Paulo, 1940. Série Brasiliana.

10). - COARACY, Vivaldo - "O Rio de Janeiro no Século 17". Livraria José Olímpio Editôra. Rio de Janeiro, 1944.

11). - COUTO, Carlos de Paula - "Paleontologia Brasileira - Mamiferos". - Ministério da Educação e Saúde. Instituto Nacional do Livro. Rio de Janeiro, 1953. Imprensa Nacional.

12). - CRULS, Gastão - "Aparência do Rio de Janeiro (Notícia histórica e descritiva da cidade)". Primeiro volume. 2a. ed. Livraria José Olímpio Editôra. Rio de Janeiro, 1952.

13). - GUENOT, Lucien - "L'Évolution Biologique. Les Faits. Les Incertitudes". Masson et Cie. Éditeurs. Paris, 1951.

14). - DARDEL, Eric - "Les Pêches Maritimes". Presses Universitaires de France. Paris, 1946. Col. "Que Sais Je?".

15). - DEBANE', Nicolau José - “A Pesca e os Pescadores no Brasil", Rio de Janeiro. Imprensa Nacional, 1924.

16) . - ELLIS JúNIOR, Alfredo - "O Ouro e a Paulistânia". Boletim n.* XCVI da Faculdade de Filosofia, Ciências e Letras da Universidade de São Paulo. História da Civilização Brasileira, n. ${ }^{\circ}$. São Paulo, 1948. 
17). - ElLIS, Myriam - "O Monopólio do Sal no Estado do Brasil (1631-1801). (Contribuição ao estudo do monopólio comercial português no Brasil, durante o período colonial)". Boletim n. 197 da Facullade de Filosofia, Ciências e Letras da Universidade de São Paulo. História da Civilização Brasileira, n. ${ }^{\circ}$ 14. São Paulo, 1955.

18) . - ENCYCLOPEDIA BRITANNICA - vol. 5, "Cetacea"; vol. 23, "Whale Fisheries". Britannica, Inc. 1952. U.S.A.

19) . - FREIRE, Felisbello - "História da Cidade do Rio de Janeiro (1500-1900)". 1. $0^{\circ}$ volume, $10^{\circ}$ fasciculo. Rio de Janeiro, 1901. Companhia Typ. do Brasil.

20). - HJORT, Johan and RUUD, Johan T. - "Whaling and Fishing in the North Atlantic". In "Rapports et Procès Verbaux des Réunions", vol. LVI. Conseil Permanent International pour l'Exploration de la Mer. - "Whales and Plankton in the North Atlantic. A contribution to the work of the whaling committee and of the north eastern area committee". (En Commission Chez Andr. Fred. Host. \& Fils. Copenhague. Mai, 1929).

21) . - HOLANDA, Sérgio Buarque de - "Antologia dos Poetas Brasileiros da Fase Colonial". Ministério da Educação e Saúde. Instituto Nacional do Livro. Departamento de Imprensa Nacional. Rio de Janeiro, 1953.

22) . - IHERING, Rodolpho von - "Dicionario dos Animais do Brasil". São Paulo, 1940. Secretaria da Agricultura, Inìustria e Comércio do Estado de São Paulo. Diretoria de Publicidade Agrícola. Tip. Brasil.

23) . - JOUAN, Henri - "La Chasse et la Pêche des Animaux Marins". Paris, s-d., Librairie Germer Baillière et Cie. Bibliothèque utile.

24). - KRAUL, Capitaine - "Chasses à la Baleine". Traduit de l'allemand par E. Vincent e H. Lebarraque. Fernand Sorlot. Paris. 1943.

25). - LULL, Richard Swann - "Organic Evolution". New York, 1940. The Macmillan Company.

26) . - MACEDO, Jorge de — "A situação econômica no tempo de Pombal - alguns aspectos". Livraria Portugália. Pốrto, 1951. (Col. Estudos e Documentos para a História de Portugal) .

27) . - MEUNIER, Victor - "Les grandes pêches". Troisième édition. Paris, 1878. Librairie Hachette et Cie. Typ. Lahure.

28) . - NAINTRE', Loïe, ODDENINO, C., LAURENS, N. - "La pêche en Mer". Les Editions Prisma. (Petite Encyclopedia Prisma de la Pêche). Paris, 1948.

29) . - NQRMAN, F. L. S. an FRASER, D. Ss., F. L. S. - "Field Book of Giant Fishes". New York, 1949. G. P. Putnam's Sons.

30). - PERRIER, Edmond - "A Travers le Monde Vivant". Paris, 1916. Ernest Flammarion Editeur.

31). - PINHEIRO, José Feliciano Fernandes (Visconde de São Leopoldo) - “Anais da Província de São Pedro". Rio de Janeiro, 1946. Imprensa Nacional. Instituto Nacional ido Livro. Ministério da Educação e Saúde. 
32). - Póto SEguro, Visconde de - "História Geral do Brasil”. Tomo V. 3a. edição. Cia. Melhoramentos de São Paulo. São Paulo, s-d.

33) . - PRADO JÚNIOR, Caio - "História Econômica do Brasil". Editôra Brasiliense Limitada. São Paulo, 1945.

34) . - PRADO JÚNIOR, Caio - "Formação do Brasil Contemporâneo - Colônia". Livraria Martins Editôra. São Paulo, 1942.

35) . - RATTON, Jacome — "Recordaçôes de..., fidalgo Cavalleiro da Caza Real, Cavalheiro da Ordem de Christo, ex-negociante da praça de Lisboa, e deputado do tribunal supremo da real junta do comercio, agricultura, fabricas e navegação, sobre ocurrencias de seu tempo em Portugal... de maio de 1747 a setembro de $1810 . . . "$. Londres, 1813. H. Bryer.

36). - ROBERTSON, R. B. - "Avec les Chasseurs de Baleines". Traduit de l'anglais par Jean Gravand. Amiot-Dumont. Paris, 1955 .

37) . - RODRIGUES, F. Contreiras - "Traços da Economia Social e Política do Brasil". Ariel Editôra Limitada. Rio de Janeiro, 1935 .

38) . - RƯSPOLI, Mário - “À la Recherche du Cachalot”. Paris, 1955. Editions de Paris.

39) . - SANTOS, Eurico - "Entre o Gambá e o Macaco. (Vida e Cos_ tumes dos Mamíferos no Brasil)". Rio de Janeiro, 1945. F. Briguiet \& Cia.

40). - SANTOS, Francisco Martins dos - "Bertioga Histórica e Legendária, 1531-1947". Ed. Armando Lichti. Tip. do Brasil. Santos, 1948.

41). - SARAIVA, José Mendes da Cunha - "Companhia Geral de Pernambuco e Paraíba". Congresso do Mundo Português, X volume, tomo II, II seção. Lisboa, 1940. Of. Bertrand Irmão.

42). - SILVA, Ignacio Accioli de Cerqueira e -Memórias Históricas e Políticas da Bahia", vols. I, III. Bahia, Imprensa Oficial do Estado. 1919, 1931.

43). - SILVA, José Bonifácio de Andrada e - 'Memoria sobre a Pesca das Baleias, e Extracção do seu Azeite; com algumas reflexões a respeito das nossas Pescarias, por...". In "Memorias Economicas da Academia Real das Sciencias de Lisboa, para o adiantamento da Agricultura, das Artes, e da Industria em Portugal, e suas conquistas"' Lisboa. Na Officina da mesma Academia. Anno M.DCC.XC.

44). - SIMONSEN, Roberto - "História Econômica do Brasil 1500-1820", tomo II. Companhia Editôra Nacional. São Paulo, 1937. Série Brasiliana.

45). - SOUSA, Alberto - "Os Andradas". Volume I. São Paulo, 1922. Typ. Piratininga .

46) . - TAUNAY, Affonso de E. - “Monstros e Monstrengos do Brasil (Ensaio sôbre a zoologia fantástica brasileira nos séculos XVII e XVIII)". São Paulo, 1937. Imprensa Oficial do Estado de São Paulo.

47). - TAUNAY, Affonso de E. - "Na Bahia de D. João.VI". Bahia, 1928. Imprensa Oficial do Estado.

48). - TAUNAY, Affonso de E. - "No Rio de Janeiro de Antanho (Impressōes de viajantes Estrangeiros). São Paulo, 1942. Companhia Editôra Nacional. Série Brasiliana. 
49) . - TAVORA FILHO, Elysiário - "José Bonifácio, Cientista, Professor e Técnico". Rio de Janeiro, 1944. Livraria Ed. Casa do Estudante do Brasil.

50). - VILlaR, Frederico - "Pelas Industrias da Pesca no Brasil". Rio de Janeiro, 1911. Livraria Garnier.

51). - WÄTJEN, Hermann - "O Domínio Colonial Hollandez no Brasil”. Tradução de Pedro Celso Uchôa Cavalcanti. Companhia Editôra Nacional. São Paulo, 1938. Série Brasiliana.

\section{ARTIGOS DE PUBLICAÇõES PERIÓdICAS.}

1). - "A Pesca da Baleia no Brasil" - Revista Americana. Março de 1913. Tomo I. Fascículo III. Rio de Janeiro, 1913. Imprensa Nacional.

2) . - ALMEIDA, A. Paulino de - "A Pesca da Baleia". Correio Paulistano de 30 de novembro de 1934 . São Paulo.

3) . - ALMEIDA, A. Paulino de - "Bom Abrigo" Revista do Instituto Histórico e Geográfico de São Paulo, vol. XXXIV. Edição do mesmo Instituto. São Paulo, 1938. Sociedade Impressôra Brasileira. Brusco \& Cia.

4) . - ALVIM, Miguel de Souza Mello e - "A Pesca da Baleia em Santa Catharina". Revista do Instituto Histórico e Geographico de Santa Catarina, vol. III, 1914. Florianópolis. Typ. da Escola Artífices.

5) . - BARroS, J. Teixeira - "A Pesca da Baleia na Bahia". Separata da Revista do Instituto Geographico e Historico da Bahia. Ano VII, vol. VII, n. ${ }^{\circ} 23$. Bahia, 1900. Typ. e Enc. Empreza Editôra.

6). - BOITEUX, L. A. - "A Pesca da Baleia". Revista do Instituto Historico e Geographico de Santa Catharina, vol. 'III. 1914. Florianópolis. Typ. da Escola Artífices.

7). - BOSCHMA, H. - "Remarques sur les Cétacés à dents, et en particulier sur le Cachalot". - Bulletin de L'Institut Océanographique, n. ${ }^{\circ} 91,30$ Avril, 1951. Monaco. Imprimerie Nationale de Monaco.

8). - BRAGA, José M. - "A Balaenoptera da Praia do Paraiso". Boletim da Associaçẫo da Filosofia Natural, vol. I. Julho, 1940, n. ${ }^{\circ}$ 12. Pôrto, 1939. Empresa Industrial Gráfica do Pôrto Ltda.

9). - CARCELLES, Alberto - "Los cetáceos en las aguas argentinas". Reimpresión de Argentina Austral. Año XX, numero 205 . Octubre, 1948, Buenos Aires.

10) . - DIEGUES JÚNIOR, Manuel - "As Companhias Privilegiadas no Comércio Colonial". Revista de História n. ${ }^{\circ}$ 3, São Paulo, julho-setembro de 1950 . Ano I.

11). - FAZENDA, José Vieira - "Antiqualhas e Memorias do Rio de Janeiro". Revista do Instituto Histórico e Geográfico Brasileiro, tomo 88, vol. 142. 1920. Rio de Janeiro, 1923. Imprensa Nacional.

12). - KELlOGG, Remington - "Whales, Giants of the Sea". The National Geographical Magazine, January, 1940. Volume LXXVII, number one. Publ. by the National Geographic Society. Washington. 
13) . LACOMBE, Américo Jacobina - "Baleias e Armações", Digesto Econômico, n. ${ }^{\circ}$ 30. Maio de 1947 . Ano III. São Paulo.

14). - MATTHEWS, L. Harrison - “A Baleia e a sua pesca”. Trad. da Revista "Endeavour", da Inglaterra. Revista Duperial do Brasil, n. ${ }^{\circ} 36$. Março-abril, 1947.

15) . - RIBEIRO, Alípio de Miranda - "A nova instalação dos Cetaceos no Museu". Boletim do Muse u Nacional, vol. VI, n. ${ }^{\circ}$ 4, dezembro. Rio de Janeiro, 1930.

16). - SA', Luiz de França Almeida e - "Armações da Pesca da Baleia". Revista do Instituto Histórico e Geográfico Brasileiro. Tomo LXII, parte II. Rio de Janeiro, 1900. Imprensa Nacional.

17). - TAUNAY, Affonso de E. - "Em Santa Catharina Colonial - Capítulo da história do povoamento". Annaes do Museu Paulista, tomo $7 .^{\circ}$. São Paulo, 1936. Imprensa Official do Estado.

18). - TAUNAY, Affonso de E. - “Na Bahia Colonial (1610-1774). Impressões de Viajantes Estrangeiros". Separata da Revista do Instituto Histórico e Geográfico Brasileiro. Tomo 90, vol. 144. 1921. Rio de Janeiro, 1925, Imprensa Nacional.

19) . - TAUNAY, Affonso de E. - "Santa Catharina nos Annos Primevos". Annaes do Museu Paulista, tomo 4.․ São Paulo, 1931. Diário Oficial.

\section{MYRIAM ELLIS}

Assistente da Cadeira de História da Civilização Brasileira da Faculdade de Filosofia, Ciências e Letras da Universidade de Sāo Paulo. 
II) - Arquivo Nacional. Rio de Janeiro.

8). - "Assento que se faz com Domingos Gomes da Costa para estabelecer á sua custa uma nova Armação nas Costas das Capitanias de São Paulo e Santos em que pediu por provisão se lhe registrasse...". Coleção de Ordens Régias, $n$. 64, Livro 3.

9) . - "Cartas Régias. Provisões, Alvarás e Avisos". 16621821. Em avulso, vol. 37; Cartas Régias, vol. 161; Em avulso, vol. 16; Vol. 26. Coleção de Ordens Régias, n. 64, Livro 3.

10). - "Correspondência dos Governadores do Rio de Janeiro com diversas autoridades". Coleçâo 84, Livro III.

11). - "Correspondência dos Governadores do Rio de Janeiro com diversas autoridades". Coleção 84. Livro XIII.

III). - Biblioteca Nacional. Rio de Janeiro.

12). - "Carta do Conde dos Arcos, datada do Rio de Janeiro a 28 de Fevereiro de 1807, ao Capitão Tenente Pedro Antonio Nunes, sôbre as providências a serem tomadas contra os navios estrangeiros que praticavam a pesca volante das baleias no litoral de Santa Catarina até o Rio da Prata", com vários "Anexos", sôbre o mesmo assunto.

13). - "Projeto do Alvará abolindo o Contrato da pescaria de baleias e do estanque do sal no Brasil e estabelecendo ou. tros impostos que vigorarão a partir de 1 de Abril de 1801 .

IV). - Departamento do Arquivo do Estado de São Paulo.

14). - “Avisos e Cartas Régias", 1765-1767. Livro Manuscrito, 169. Tempo Colonial.

15). - “Avisos e Cartas Régias", 1778-1796. Livro Manuscrito, 171. Tempo Colonial.

16). - "Avisos e Cartas Régias", 1796-1802. Livro Manuscrito 173. Tempo Colonial.

17). - "Patentes e Cartas Régias", 1745-1765. Livro Manuscrito 51. Tempo Colonial.

18). - "Maço de População de Santos". 1765-1799. Tempo Colonial.

19) . - "Maço de População de São Sebastião". 1765-1797. Tempo Colonial.

20). - "Provisões Régias". 1746-1763. Livro Manuscrito 189. Tempo Colonial.

21). - "Registro das Condições e assento com o alvará com que foi arrematado a Tomé Gomes Moreira o Contrato da Armação das Baleias da Capitania do Rio de Jareiro, 
Santos e São Paulo...". Com mais documentos anexos. Livro Manuscrito 51 . Tempo Colonial, "Patentes e Cartas Régias". 1745-1765.

V). - Instituto Histórico e Geográfico Brasileiro.

22). - Conselho Ultramarino. "Vúrios", tomo 5.

CRONISTAS, INFORMANTES E VIAJANTES.

1). - ANCHIETA, José de - "Informação da Provincia do Brasil para Nosso Padre. 1585". In "Cartas, Informações, Fragmentos Historicos e Sermóes do Padre..." (1554-1594). Publicação da Academia Brasileira. Rio de Janeiro, 1933. Civilização Brasileira, A. S. - Atribuida ao Pe. José de Anchieta, na verdade foi escrita pelo Pe. Fernão Cardim, segundo o Pe. Serafim Leite, que a encontrou no Arquivo da Companhia de Jesus, em Roma. (Códice Brasília 15, 333339 , ou seja a "Informação da provincia do Brasil para nosso Padre", datada da Bahia a 31 de dezembro de 1583) José Honório Rodrigues - "Historiografia del Brasil, siglo XVI, México, 1957. Instituto Panamericano de Geografia e História.

2). - ANONIMO - "De Algumas cousas mais notaveis do Brasil". (Informação jesuítica de fins do Século XVI). Revista do Instituto Histórico é Geográfico Brasileiro, tomo 94, vol. 148. 1923. Rio de Janeiro, 1927. Imprensa Nacional.

3). - ARAúJo, José de Souza Azevedo Pizarro e - "Memorias Historicas do Rio de Janeiro". 9 volumes. Ministério da Educação e Saúde. Instituto Nacional do Livro. Imprensa Nacional. Rio de Janeiro, 1945-1948.

4) . - BRITO, Paulo Jozé Miguel de — "Memoria Politica sobre a Capitania de Santa Catarina. Escrita no Rio de Janeiro em o anno de 1816 por...". Lisboa. Typ. da Academia Real das Sciencias. 1829 .

5). - CALDAS, José Antonio - "Noticia Geral dé Toda esta Capitania da Bahia desde o seu descobrimento até o Presente ano de 1759". Ed. Fac-Similar. Tipografia Beneditina Ltda. Salvador, 1951.

6) . - CARDIM, Fernão - "Tratados da Terra e Gente do Brasil". Introdução e notas de Baptista Caetano, Capistrano de Abreu e Rodolfo Garcia. 2a. ed. Companhia Editôra Nacional. São Paulo, 1939. Série Brasiliana.

7). - CASAL, Aires de - "Corografia Brasílica", tomo II. FacSímile da ed. de 1817. Ministério da Educação e Saúde. Instituto Nacional do Livro. Imprensa Nacional. Rio de Janeiro, 1947.

8). - DAMPIER, Guillaume - "Voyage aux terres Australes, à la nouvelle Hollande \&C. fait en 1699. Où l'on trouve la Description des Isles Canaries, des Isles de Mayo \& de S. Iago, de la Baye de Tous des Saints, des Forts \& de la Ville de Bahia dans le Brésil, \&C. Par...". Tome IV. A' Rouen. Chez Eustache Herault. (Cour du Palais). M.DCC.XV.

9) . - DENIS, Ferdinand — "Brésil". Paris, MDCCCXXXVII. Firmin Didot Frères Editeurs. 
10). - FREYRE, Francisco de Brito - "Viagem da Armada da Companhia do Commercio, e Frotas do Estado do Brasil. A Cargo do General Francisco de Brito Freyre". Impressa por mandado de El Rey Nosso Senhor. Anno 1655.

11). - GANDAvO, Pero de Magalhães - "Historia da Provincia de Santa Cruz". Edição da Typ. do Annuario do Brasil. Rio de Janeiro, 1924 .

12) . - KIDDER, D. P. e FLETCHER, J. C. — "O Brasil e os Brasileiros" (Esbôço Histórico e Descritivo). 2. vol. Trad. de Elias Dolianiti. Cia. Editôra Nacional. São Paulo, 1941. Série Brasiliana.

13). - KNIVET", Antonie - "The admirable adventures and strange fortunes of Master..., which went with Master Thomas Candish in his second voyage to the South Sea. 1591. In Samuel Purchas. B. D. Hakluytus Posthumus or Purchas His Pilgrimes, XVI. Glasgow, 1906.

14) . - LERY, Jean de — "Viagem à Terra do Brasil". Trad. e notas de Sérgio Milliet. São Paulo, 1941. Livraria Martins. Biblioteca Histórica Paulista, vol. VIr. Emp. Gráf. Revista dos Tribunais.

15). - MARTIUS, C. F. P. e SPIX, J. B. von - "Viagem pelo Brasil". Tradução de Lucia Furquim Lahmeyer. Rev. por B. F. Rạmiz Galvão e B. de Magalhães que foi também o anotador. $2 .^{\circ}$ vol. R. de Janeiro, 1938. Imprensa Nacional.

16) . - MAWE, John - "Viagens ao Interior do Brasil, principalmente aos distritos de ouro e dos diamantes". Tradução de Solena Benevides Viana. Introd. e notas de Clado Ribeiro de Lessa. Rio de Janeiro, 1944. Ed. Zélio Valverde.

17) . - PITTA, Sebastião da Rocha - "História da America Portugueza des'de o ano de mil e quinhentos do seu descobrimento até o de mil e setecentos e vinte e quatro". 2a. edição, revista e anotada por J. G. Goes. Lisboa, M. DCCCLXXX. Ed. Francisco Arthur da Silva.

18) . - PYRARD, de Laval, François - "Extracto das Viagens de... relativo à estada deste navegante no Brazil em 1610". Tradução de Affonso d'Escragnolle Taunay. Revista do Institituto Histórico e Geográfico de São Paulo, vol. XIII. 1908. São Paulo, 1911. Typ. do Diário Oficial.

19) . - SAINT-HILAIRE, Auguste — "Viagem à Provincia de Santa Catharina (1820)". Tradução de Carlos da Costa Pereira. São Paulo, 1936. Companhia Editôra Nacional. Série Brasiliana.

20) . - SALVADOR, Frei Vicente do - "História do Brasil, 15001627". Terceira edição revista por Capistrano de Abreu e Rodolpho Garcia. Companhia de Melhoramentos de São Paulo. São Paulo, s.-d.

21). - SEIDLER, Carl - "Dez anos no Brasil". Tradução e notas do General Bertoldo Klinger. São Paulo. Livraria Martins. s-d. Biblioteca Histórica Brasileira, vol. VIII.

22) . - SoUSA, Gabriel Soares de - "Tratado Descriptivo do Brasil em 1587". Comentários de Francisco Adolpho Varnhagen. Terceira edição. Companhia Editôra Nacional. São Paulo, 1938. Série Brasiliana. 
23) . - VASCONCELlOS, Simão de - "Noticias curiosas e necessarias das cousas do Brasil. Pello Padre... da Companhia de Iesus". Em Lisboa. Na Officina de Ioam da Costa. Anno 1668 .

24) . - VILHENA, Luiz dos Santos - "Recopilação de Noticias Soteropolitanas e Brasilicas". 2 volumes. Bahia, 1921. Imprensa Official do Estado.

\section{OBRAS GERAIS E ESPECIALIZADAS.}

(1) . - AZEVEDO, J. Lúcio de - "Novas Epanáforas". Livraria Clás. sica Editôra. Lisboa, 1932.

2) . - AZEVEDO, J. Lúcio de - "Epocas de Portugal Econômico - Esboços de História”. 2a. edição. Livraria Clássica Editôra. Lisboa, 1947.

3) . - AZEvedoo, J. Lúcio de - "O Marquês de Pombal e a sua época". Segunda edição. Editôres: Annuario do Brasil. Rio de Janeiro. Seara Nova. Lisboa. Renascenca Portuguesa. Pôrto (Typographia Annuario do Brasil). (Almanack Laemmert). Rio de Janeiro, 1922.

4). - BALBI, Adrien - "Essai Satistique sur le Royaume de Portugal et d'Algarve Comparé aux autres états de l'Europe". Tome premier. Paris, chez Rey et Gravier Libraires, 1822.

5) . - BEIRÃO, Caetano - “D. Maria I (1777-1792)". Terceira edisão. Lisboa, 1944. Emprêsa Nacional de Publicidade.

6) . - BESNARD, Wladimir - "Les produits d'Origine Marine et Fluviale". Paris, 1948. Payot.

7). - CAMARA, Antonio Alves - "Ensaio sobre as Construccões Navaes Indigenas do Brasil". Rio de Janeiro, 1888. Typ. de G. Leuzinger \& Filhos.

8) . - CAMARA, Antonio Alves - "Pescas e Peixes da Bahia". Rio de Janeiro, 1911. Typ. Leuzinger.

9). - CARnaXIDE, Antonio de Sousa Pedroso de (Visconde de Carnaxide) - "O Brasil na Administração Pombalina (Economia e Politica Externa)". Companhia Editôra Nacional. São Paulo, 1940. Série Brasiliana.

10). - COARACY, Vivaldo - "O Rio de Janeiro no Século 17". Livraria José Olímpio Editôra. Rio de Janeiro, 1944.

11) . CouTo, Carlos de Paula - "Paleontologia Brasileira - Mamiferos". - Ministério da Educação e Saúde. Instituto Nacional do Livro. Rio de Janeiro, 1953. Imprensa Nacional.

12) . - CRULS, Gastão - "Aparência do Rio de Janeiro (Notícia histórica e descritiva da cidade)". Primeiro volume. 2a. ed. Livraria José Olímpio Editôra. Rio de Janeiro, 1952.

13). - CUENOT, Lucien - "L'Évolution Biologique. Les Faits . Les Incertitudes". Masson et Cie. Éditeurs. Paris, 1951.

14) . - DARDEL, Eric - "Les Pêches Maritimes". Presses Universitaires de France. Paris, 1946. Col. "Que Sais Je?”.

15). - DEBANE", Nicolau José - "A Pesca e os Pescadores no Brasil", Rio de Janeiro. Imprensa Nacional, 1924.

16) . - ELLIS JúNIOR, Alfredo - "O Ouro e a Paulistânia". Boletim n. XCVI da Faculdade de Filosofia, Ciências e Letras da Universidade de São Paulo. História da Civilização Brasileira, n..$^{\circ}$. São Paulo, 1948. 
17). - ELLIS, Myriam - "O Monopólio do Sal no Estado dó Brasil (1631-1801) . (Contribuição ao estudo do monopólio comercial português no Brasil, durante o periodo colonial)". Boletim n. 197 da Faculidade de Filosofia, Ciências e Letras da Universidade de São Paulo. História da Civilização Brasileira, n. ${ }^{\circ}$ 14. São Paulo, 1955.

18). - ENCYCLOPEDIA BRITANNICA - vol. 5, "Cetacea"; vol. 23, "Whale Fisheries". Britannica, Inc. 1952. U.S.A.

19) . - FREIRE, Felisbello - "História da Cidade do Rio de Janeiro (1500-1900)". 1. volume, 1.० fascículo. Rio de Janeiro, 1901. Companhia Typ. do Brasil.

20) . - HJORT, Johan and RUUD, Johan T. — "Whaling and Fishing in the North Atlantic". In "Rapports et Procès Verbaux des Réunions", vol. LVI. Conseil Permanent International pour l'Exploration de la Mer. - "Whales and Plankton in the North Atlantic. A contribution to the work of the whaling committee and of the north eastern area committee". (En Commission Chez Andr. Fred. Host. \& Fils. Copenhague. Mai, 1929).

21). - HOLANDA, Sérgio Buarque de - "Antologia dos Poetas Brasileiros da Fase Colonial". Ministério da Educação e Saúde. Instituto Nacional do Livro. Departamento de Imprensa Nacional. Rio de Janeiro, 1953.

22). - IHERING, Rodolpho von - "Dicionario dos Animais do Bra. sil". São Paulo, 1940. Secretaria da Agricultura, Indústria e Comércio do Estado de São Paulo. Diretoria de Publicidade Agrícola. Tip. Brasil.

23). - JOUAN, Henri - "La Chasse et la Pêche des Animaux Marins". Paris, s-d., Librairie Germer Baillière et Cie. Bibliothèque utile.

24). - KRAUL, Capitaine - "Chasses à la Baleine". Traduit de l'allemand par E. Vincent e H. Lebarraque. Fernand Sorlot. Paris. 1943.

25). - LULL, Richard Swann - "Organic Evolution". New York, 1940. The Macmillan Company.

26) . - MACEDO, Jorge de - "A situação econômica no tempo de Pombal - alguns aspectos". Livraria Portugália. Pốrto, 1951. (Col. Estudos e Documentos para a História de Portugal).

27). - MEUNIER, Victor - "Les grandes pêches". Troisième édition. Paris, 1878. Librairie Hachette et Cie. Typ. Lahure.

28). - NAINTRE', Loïe, ODDENINO, C., LAURENS, N. - "La pêche en Mer". Les Editions Prisma. (Petite Encyclopedia Prisma de la Pêche). Paris, 1948.

29) . - NORMAN, F. L. S. an FRASER, D. Ss., F. L. S. - "Field Book of Giant Fishes". New York, 1949. G. P. Putnam's Sons.

30). - PERRIER, Edmond - “A' Travers le Monde Vivant". Paris, 1916. Ernest Flammarion Éditeur.

31) . - PINHEIRO, José Feliciano Fernandes (Visconde de São Leopoldo) - "Anais da Provincia de São Pedro". Rio de Janeiro, 1946. Imprensa Nacional. Instituto Nacional ido Livro. Ministério da Educação e Saúde. 
32) . - Porto SEguro, Visconde de - "História Geral do Brasil". Tomo V. 3a. edição. Cia. Melhoramentos de São Paulo. São Paulo, s-d.

33) . - PRADO JUNIOR, Caio - "História Econômica do Brasil". Editôra Brasiliense Limitada. São Paulo, 1945.

34) . - PRADO JUNIOR, Caio - "Formação do Brasil Contemporâneo - Colônia". Livraria Martins Editôra. São Patulo, 1942.

35) . - RATTON, Jacome - "Recordações de..., fidalgo Cavalleiro da Caza Real, Cavalheiro da Ordem de Christo, ex-negociante da praça de Lisboa, e deputado do tribunal supremo da real junta do comercio, agricultura, fabricas e navegação, sobre ocurrencias de seu tempo em Portugal... de maio de 1747 a setembro de $1810 . . . "$. Lonidres, 1813. H. Bryer.

36) . - ROBERTSON, R. B. - "Avec les Chasseurs de Baleines". Traduit de l'anglais par Jean Gravand. Amiot-Dumont. Paris, 1955.

37) . - RODRIGUES, F. Contreiras - "Traços da Economia Social e Política do Brasil". Ariel Editôra Limitada. Rio de Janeiro, 1935 .

38). - RUSPOLI, Mário _- “À la Recherche du Cachalot”. Paris, 1955. Editions de Paris.

39) . - SANTOS, Eurico - "Entre o Gambá e o Macaco. (Vida e Cos. tumes dos Mamíferos no Brasil)". Rio de Janeiro, 1945. F. Briguiet \& Cia.

40). - SANTOS, Francisco Martins dos - "Bertioga Histórica e Legendária, 1531-1947". Eid. Armando Lichti. Tip. do Brasil. Santos, 1948.

41). - SARAIVA, José Mendes da Cunha - "Companhia Geral de Pernambuco e Paraiba". Congresso do Mundo Português, X volume, tomo II, II secção. Lisboa, 1940. Of. Bertrand Irmão.

42) . - SILVA, Ignacio Accioli de Cerqueira e - "Memórias Históricas e Políticas da Bahia", vols. I, III. Bahia, Imprensa Oficial do Estado. 1919, 1931.

43). - SILVA, José Bonifácio de Andrada e - 'Memoria sobre a Pesca das Baleias, e Extracção do seu Azeite; com algumas reflexões a respeito das nossas Pescarias, por...". In "Memorias Economicas ida Academia Real das Sciencias de Lisboa, para o adiantamento da Agricultura, das Artes, e da Industria em Portugal, e suas conquistas". Lisboa. Na Officina da mesma Academia. Anno M.DCC.XC.

44). - SIMONSEN, Roberto - "História Econômica do Brasil 1500-1820", tomo II. Companhia Editôra Nacional. São Paulo, 1937. Série Brasiliana.

45). - SOUSA, Alberto - "Os Andradas". Volume I. São Paulo, 1922. Typ. Piratininga.

46). - TAUNAY, Affonso de E. - "Monstros e Monstrengos do Brasil (Ensaio sôbre a zoologia fantástica brasileira nos séculos XVII e XVIII)"'. São Paulo, 1937. Imprensa Oficial do Estado de São Paulo.

47). - TAUNAY, Affonso de E. — "Na Bahia de D. João,VI". Bahia, 1928. Imprensa Oficial do Estado.

48) . - TAUNAY, Affonso de E. - "No Rio de Janeiro de Antanho (Impressões de viajantes Estrangeiros). São Paulo, 1942. Companhia Editôra Nacional. Série Brasiliana. 
49). - TAVORA FILHO, Elysiário - "José Bonifácio, Cientista, Professor e Técnico". Rio de Janeiro, 1944. Livraria Ed. Casa do Estudante do Brasil.

50). - VILLAR, Frederico - "Pelas Industrias da Pesca no Brasil". Rio de Janeiro, 1911. Livraria Garnier.

51) . - WÄTJEN, Hermann - “O Domínio Colonial Hollandez no Brasil”. Tradução de Pedro Celso Uchôa Cavalcanti. Companhia Editôra Nacional. São Paulo, 1938. Série Brasiliana.

\section{ARTIGOS DE PUBLICAÇÕES PERIóDicas.}

1). - "A Pesca da Baleia no Brasil" - Revista Americana. Março de 1913. Tomo I. Fascículo III. Rio de Janeiro, 1913. Imprensa Nacional.

2) . - AlMEIDA, A. Paulino de - "A Pesca da Baleia". Correio Paulistano de 30 de novembro de 1934. São Paulo.

3) . - ALMEIDA, A. Paulino de - "Bom Abrigo" Revista do Instituto Histórico e Geográfico de São Paulo, vol. XXXIV. Eddição do mesmo Instituto. São Paulo, 1938. Sociedade Impressôra Brasileira. Brusco \& Cia .

4) . - ALVIM, Miguel de Souza Mello e - "A Pesca da Baleia em Santa Catharina". Revista do Instituto Histórico e Geographico de Santa Catarina, vol. III, 1914. Florianópolis. Typ. da Escola Artífices.

5) . - BARros, J. Teixeira - "A Pesca da Baleia na Bahia". Separata da Revista do' Instituto Geographico e Historico da Bahia. Ano VII, vol. VII, n.*23. Bahia, 1900. Typ. e Enc. Empreza Editôra.

6). - BOITEUX, L. A. - "A Pesca da Baleia". Revista do Instituto Historico e Geographico de Santa Catharina, vol. III. 1914. Florianópolis. Typ. da Escola Artifices.

7). - BOSCHMA, H. - "Remarques sur les Cétacés à dents, et en particulier sur le Cachalot". - - Bulletin de L'Institut Océanographique, n.॰ 991, 30 Avril, 1951. Monaco. Imprimerie Nationale de Monaco.

8). - BRAGA, José M. - “A Balaenoptera da Praia do Paraiso". Boletim da Associação da Filosofia Natural, vol. I. Julho, 1940, n. ${ }^{\circ}$ 12. Pôrto, 1939. Empresa Industrial Gráfica do Pôrto Ltda.

9). - CARCELLES, Alberto - "Los cetáceos en las aguas argentinas”. Reimpresión de Argentina Austral. Año XX, numero $20 j$. Octubre, 1948, Buenos Aires.

10). - DIÉgues JúNIOR, Manuel — "As Companhias Privilegiadas no Comércio Colonial". Revista de História n..$^{\circ}$, São Paulo, julho-setembro de 1950. Ano I.

11). - FAZENDA, José Vieira - "Antiqualhas e Memorias do Rio de Janeiro". Revista do Instituto Histórico e Geográfico Brasileiro, tomo 88, vol. 142. 1920. Rio de Janeiro, 1923. Imprensa Nacional.

12). - KELLOGG, Remington - "Whales, Giants of the Sea". The National Geographical Magazine, January, 1940. Volume LXXVII, number one. Publ. by the National Geographic Society. Washington. 
13) . - LACOMBE, Américo Jacobina - "Baleias e Armações", Digesto Econômico, n. ${ }^{\circ} 30$. Maio de 1947. Ano III. São Paulo.

14). - MATTHEWS, L. Harrison - "A Baleia e a sua pesca". Trad. da Revista "Endeavour", da Inglaterra. Revista Duperial do Brasil, n. ${ }^{\circ} 36$. Marco-abril, 1947.

15) . - RIBEIRO, Alípio de Miranda - "A nova instalação dos Cetaceos no Museu". Boletim do Museu Nacional, vol. VI, n. ${ }^{\circ}$ 4, dezembro. Rio de Janeiro, 1930.

16). - SA', Luiz de França Almeida e - "Armações da Pesca da Baleia". Revista do Instituto Histórico e Geográfico Brasileiro. Tomo LXII, parte II. Rio de Janeiro, 1900. Imprensa Nacional.

17). - TAUNAY, Affonso de E. - "Em Santa Catharina Colonial - Capítulo da história do povoamento". Annaes do Museu Paulista, tomo $7 .^{\circ}$. São Paulo, 1936. Imprensa Official do Estado.

18). - TAUNAY, Affonso de E. - “Na Bahia Colonial (1610-1774) Impressões de Viajantes Estrangeiros". Separata da Revista do Instituto Histórico e Geográfico Brasileiro. Tomo 90, vol. 144. 1921. Rio de Janeiro, 1925, Imprensa Nacional.

19). - TAUNAY, Affonso de E. - "Santa Catharina nos Annos Primevos". Annaes do Museu Paulista, tomo 4.․ São Paulo, 1931. Diário Oficial.

\section{MYRIAM ELLIS}

Assistente da Cadeira de História da Civilização Brasileira da Faculdade de Filosofia, Ciências e Letras da Universidade de São Paulo. 